Review

\title{
New perspectives on the reactions of metal nitrosyls with thiolates as nucleophiles
}

\author{
Maykon Lima Souza ${ }^{\mathrm{a}}$, Antonio Carlos Roveda Jr. ${ }^{a}$, José Clayston Melo Pereira ${ }^{\mathrm{b}}$, \\ Douglas Wagner Franco ${ }^{\mathrm{a}, *}$ \\ a Instituto de Química de São Carlos, Universidade de São Paulo - USP, P.O. Box 780, CEP 13566-590 São Carlos, SP, Brazil \\ ${ }^{\mathrm{b}}$ Departamento de Química Geral e Inorgânica, Instituto de Química de Araraquara, Universidade Estadual Paulista - Unesp, P.O. Box 355, CEP 14801-970 \\ Araraquara, São Paulo, Brazil
}

\section{Contents}

1. Introduction

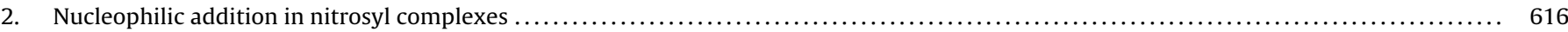

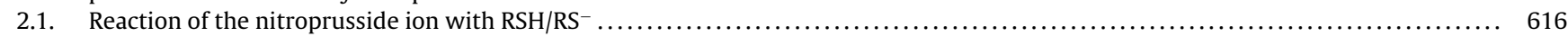

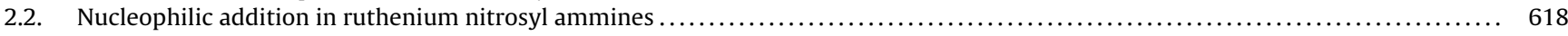

2.3. Some kinetic and electrochemical aspects of thiol and hydroxide addition in ruthenium nitrosyl complexes .................... 622

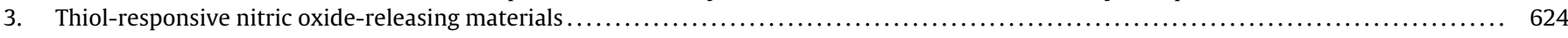

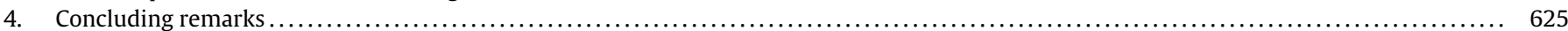

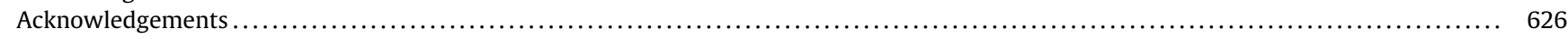

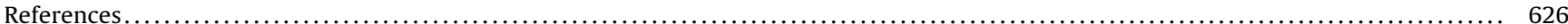

\section{A R T I C L E I N F O}

\section{Article history:}

Received 12 December 2014

Received in revised form 12 February 2015

Accepted 10 March 2015

Available online 19 March 2015

\section{Keywords:}

Nitric oxide

Nitroxyl

Nucleophilic attack

Cysteine

Glutathione

Thiol

\begin{abstract}
A B S T R A C T
The susceptibility of the nitrosonium ligand $\left(\mathrm{NO}^{+}\right)$of metal nitrosyls to nucleophilic attack has been reviewed. The reactions of nitroprusside with thiolate $\left(\mathrm{RS}^{-}\right)$nucleophiles $\left(\mathrm{H}_{2} \mathrm{~S}\right.$, cysteine, glutathione, $\mathrm{N}$-acetylcysteine and others) have been covered, albeit the main focus is on the reactivity of ruthenium nitrosyl ammines (trans- $\left[\mathrm{Ru}\left(\mathrm{NH}_{3}\right)_{4}(\mathrm{~L}) \mathrm{NO}^{+}\right]^{n+}$ ) with cysteine and glutathione. Kinetic aspects and reaction products are discussed. Nitric oxide (NO) and nitroxyl (HNO) are the primary and main nitrogen-based products of the reactions with $\mathrm{RS}^{-}$. The final nitrogen based product $\mathrm{N}_{2} \mathrm{O}$ is identified and suggested as the direct product from the dimerization reaction of HNO. The accumulated data strongly suggest that the ratio of $[\mathrm{NO}] /[\mathrm{HNO}]$ formed is dependent on the $\left[\mathrm{RS}^{-}\right] /[\mathrm{RSH}]$ ratio, which can be controlled by the experimental conditions. Some aspects of thiol-responsive nitric oxide-releasing materials are also discussed.
\end{abstract}

(c) 2015 Elsevier B.V. All rights reserved.

Abbreviations: 'py ${ }^{\text {bu }} \mathrm{S}_{4}{ }^{\prime}$, 2,6-bis(2-mercapto-3,5-di-tert-butylphenylthio)dimethylpyridine; 4-pic, 4-picoline or 4-methylpyridine; bpy, 2,2'-bipyridine; CS-RuNOisn,

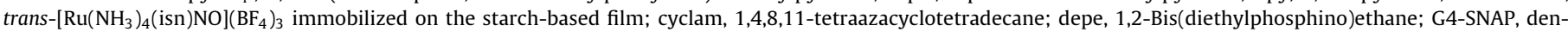

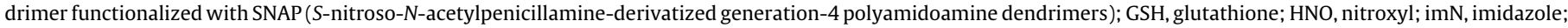

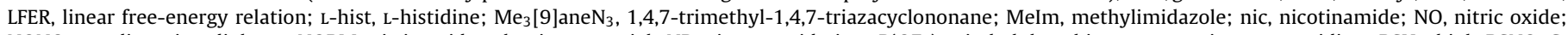

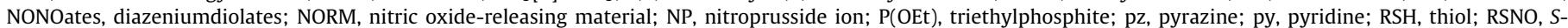
nitrosothiols; RuNOisn, trans-[ $\mathrm{Ru}\left(\mathrm{NH}_{3}\right)_{4}($ isn $\left.) \mathrm{NO}\right]\left(\mathrm{BF}_{4}\right)_{3} ; \mathrm{SCH}_{2} \mathrm{Ph}$, Benzyl mercaptan; SNAP, S-nitroso- $N$-acetylpenicillamine; ttp, tetratolylporphyrinato dianion.

* Corresponding author. Tel.: +55 1633739970.

E-mail address: douglas@iqsc.usp.br (D.W. Franco). 


\section{Introduction}

The electrophilic character of nitrosyl complexes of the type $\left[(\mathrm{L})_{5} \mathrm{M}\left(\mathrm{NO}^{+}\right)\right]^{n}$ has been verified with nucleophilic species before the 1900s [1-3]. The pentacyanonitrosylferrate(II) or nitroprusside ion $\left[\mathrm{Fe}(\mathrm{CN})_{5} \mathrm{NO}\right]^{2-}$ (abbreviated as $\mathrm{NP}$ ) was the first and most explored system for nucleophilic addition reactions between nitrosyl complexes and bases (B), such as $\mathrm{OH}^{-}$and $\mathrm{HS}^{-}$, providing the initial framework for this study (Eq. (1)) [4].

$\left[\mathrm{Fe}(\mathrm{CN})_{5}(\mathrm{NO})\right]^{2-}+\mathrm{B}^{-} \rightleftharpoons\left[\mathrm{Fe}(\mathrm{CN})_{5} \mathrm{~N}(\mathrm{O}) \mathrm{B}\right]^{3-}$

These studies were extended for a diverse class of bases that includes $\mathrm{N}$ - (ammines, hydrazine, hydroxylamine, and azide) [4-8] and S-binding species (hydrogen sulfide, sulfites, and thiols). Table 3 summarizes some constants calculated in the reaction of metal nitrosyls with thiols and $\mathrm{OH}^{-}$nucleophiles (see Section 2.3) [4,7-16]. Although the mechanisms and products of Eq. (1) with different nucleophiles were treated in a similar manner for many years, subsequent studies performed with several techniques described multiple and complex steps following the simple addition shown in Eq. (1) $[5,6,10,11]$. Recently, these reactions have received additional interest due to the biological implications of some species, such as hydroxylamine, $\mathrm{H}_{2} \mathrm{~S} / \mathrm{HS}^{-}$, cysteine, and glutathione [17-20]. This biological focus was motivated by the discovery of the physiological functions of nitric oxide in the 1980s [21-26] and, more recently, of nitroxyl (HNO) [27-30]. The possibility that the $\left[(\mathrm{L})_{5} \mathrm{MN}(\mathrm{O}) \mathrm{B}\right]^{n-1}$ adduct may be an external source of NO and/or HNO in physiological conditions has stimulated the search for new, robust, and easily modulated systems as possible sources [31,32]. In this regard, some nitrosyl complexes have been explored as nitric oxide and nitroxyl sources [10,11,33-40]. This review is mainly focused on the chemistry of the reactions between different nitrosyl complexes and the nucleophilic thiolate species $\left(\mathrm{RS}^{-}\right)$. A comparison of classical systems and ruthenium nitrosyl tetraammine complexes is performed.

\section{Nucleophilic addition in nitrosyl complexes}

Probably the first studies in this field have been carried out with the nitroprusside ion $\left[\mathrm{Fe}(\mathrm{CN})_{5} \mathrm{NO}^{2-}\right.$, using $\mathrm{OH}^{-}$and $\mathrm{H}_{2} \mathrm{~S} / \mathrm{HS}^{-}$as bases $[1,3]$. Reports on the reaction between $\left[\mathrm{Fe}(\mathrm{CN})_{5} \mathrm{NO}^{2-}\right.$ and $\mathrm{HS}^{-}$were already published in the 1850 s [1,3], and received new attention in the 1960s [4,41].

The $\left[\mathrm{Fe}(\mathrm{CN})_{5} \mathrm{~N}(\mathrm{O}) \mathrm{SH}\right]^{3-}$ adduct formed by the addition of the $\mathrm{HS}^{-}$ion to the nitrosonium ligand of nitroprusside was proposed as the product of the reaction (Eqs. (2) and (3)) [4]. This mechanism was an extension of the pathways postulated for the addition of $\mathrm{OH}^{-}$to $\left[\mathrm{Fe}(\mathrm{CN})_{5}(\mathrm{NO})\right]^{2-}$ (Eqs. (4) and (5)).

$$
\begin{aligned}
& {\left[\mathrm{Fe}(\mathrm{CN})_{5}(\mathrm{NO})\right]^{2-}+\mathrm{HS}^{-} \rightleftharpoons\left[\mathrm{Fe}(\mathrm{CN})_{5} \mathrm{~N}(\mathrm{O}) \mathrm{SH}\right]^{3-}} \\
& {\left[\mathrm{Fe}(\mathrm{CN})_{5} \mathrm{~N}(\mathrm{O}) \mathrm{SH}\right]^{3-}+\mathrm{OH}^{-} \rightleftharpoons\left[\mathrm{Fe}(\mathrm{CN})_{5} \mathrm{~N}(\mathrm{O}) \mathrm{S}\right]^{4-}+\mathrm{H}_{2} \mathrm{O}} \\
& {\left[\mathrm{Fe}(\mathrm{CN})_{5}(\mathrm{NO})\right]^{2-}+\mathrm{OH}^{-} \rightleftharpoons\left[\mathrm{Fe}(\mathrm{CN})_{5} \mathrm{~N}(\mathrm{O}) \mathrm{OH}\right]^{3-}} \\
& {\left[\mathrm{Fe}(\mathrm{CN})_{5} \mathrm{~N}(\mathrm{O}) \mathrm{OH}\right]^{3-}+\mathrm{OH}^{-} \rightleftharpoons\left[\mathrm{Fe}(\mathrm{CN})_{5} \mathrm{NO}_{2}\right]^{4-}+\mathrm{H}_{2} \mathrm{O}}
\end{aligned}
$$

The rate constants for both nucleophilic additions were calculated $[4,11,42]$ to be $k_{\mathrm{HS}}{ }^{-}=170 \pm 20 \mathrm{M}^{-1} \mathrm{~s}^{-1}$ for Eqs. (2) and (3) and $k_{\mathrm{OH}^{-}}=0.55 \mathrm{M}^{-1} \mathrm{~s}^{-1}$ for Eqs. (4) and (5). These studies already suggested that the S-binding nucleophiles were stronger bases than the $\mathrm{OH}^{-}$ions. Despite the apparent simplicity of these systems, subsequent investigations revealed complicated mechanisms for reactions with $\mathrm{HS}^{-}$and other thiols $[10,11,34]$.

It is well known that $\mathrm{OH}^{-}$addition follows a direct, reversible and non-redox reaction pathway, however recent studies $[10,11,34]$ have revealed that upon the addition of $\mathrm{HS}^{-}$to nitroprusside, the formation of $\left[\mathrm{Fe}(\mathrm{CN})_{5} \mathrm{~N}(\mathrm{O}) \mathrm{SH}\right]^{3-}$ occurs in a rapid initial step that can subsequently yield reduced nitrogen species (i.e., $\mathrm{NO}^{\bullet}, \mathrm{N}_{2} \mathrm{O}, \mathrm{NH}_{3}$ ) and a variety of substituted iron complexes (i.e., $\left[\mathrm{Fe}(\mathrm{CN})_{4} \mathrm{NO}\right]^{2-},\left[\mathrm{Fe}(\mathrm{CN})_{5}\left(\mathrm{H}_{2} \mathrm{O}\right)\right]^{3-},\left[\mathrm{Fe}(\mathrm{CN})_{6}\right]^{4-}$, and $\left[\mathrm{Fe}(\mathrm{CN})_{5-x}(\mathrm{SCN})_{x}\left(\mathrm{H}_{2} \mathrm{O}\right)\right]$ [10]). Indeed, recent data on the $\left[\mathrm{Fe}(\mathrm{CN})_{5} \mathrm{~N}(\mathrm{O}) \mathrm{SH}\right]^{3-}$ adduct led to some controversies regarding the products formed $[10,11,34]$. Due to the biological relevance of these products, this subject received renewed attention in the literature $[10,11,20,34,43,44]$. In addition, quite attention has been also directed to low molecular weight thiols on the reaction with nitroprusside ion. More details about such reactions are given in the next sections.

\subsection{Reaction of the nitroprusside ion with $\mathrm{RSH}^{\mathrm{R}} \mathrm{RS}^{-}$}

In the last few years, the reaction of NP with RSH species, e.g. $\mathrm{H}_{2} \mathrm{~S} / \mathrm{HS}^{-}$, glutathione $(\mathrm{GSH})$, cysteine and other thiols, has attracted the attention of many researchers $[10,11,34,43,44]$. The generic $\left[\mathrm{Fe}(\mathrm{CN})_{5} \mathrm{~N}(\mathrm{O}) \mathrm{SR}\right]^{(n+2)-}$ adduct is the primary product and the source of several sulfur and nitrogen reactive species, e.g. disulfide (RSSR), $\mathrm{RS}^{\bullet}, \mathrm{N}_{2} \mathrm{O}, \mathrm{NH}_{3}$ and $\mathrm{NO}[10,11,13]$. The mechanisms of formation and the chemical nature of these species are reported to be quite diversified (Scheme 1) due to the influence of $\mathrm{pH}$ and dissolved $\mathrm{O}_{2}$ on the reactions $[10,11,13,14]$. Moreover, different thermal stability and electronic features were induced in the $\left[\mathrm{Fe}(\mathrm{CN})_{5} \mathrm{~N}(\mathrm{O}) \mathrm{SR}\right]^{(n+2)}$ - adduct as function of the $\mathrm{R}$ properties $[13,14]$. In Scheme 1, we summarized the main pathways and products suggested by different authors regarding the formation and decomposition of $\left[\mathrm{Fe}(\mathrm{CN})_{5} \mathrm{~N}(\mathrm{O}) \mathrm{SR}\right]^{(n+2)-}$ under aerobic and anaerobic conditions. This will be discussed below.

Johnson et al. [14] used fast kinetic techniques (temperaturejump/stopped-flow combination) to study the formation and dissociation of the $\left[\mathrm{Fe}(\mathrm{CN})_{5} \mathrm{~N}(\mathrm{O}) \mathrm{SR}\right]^{(n+2)-}$ adduct formed by the reaction of NP with different thiols (i.e. mercaptoethanol, mercaptosuccinate, cysteine and glutathione). They found [14] that the rate constants for adduct formation with different thiols occurred in a close range (in alkaline conditions), namely $1.4-4.9 \times 10^{4} \mathrm{M}^{-1} \mathrm{~s}^{-1}$. However, the decomposition rate constants were significantly influenced by the nature of the thiol. They were affected by the presence of charged groups, such as $\mathrm{NH}_{3}{ }^{+}$and $\mathrm{COO}^{-}$, close to the $\mathrm{S}-\mathrm{NO}$ bond. For instance, the decomposition rate constant of $\left[\mathrm{Fe}(\mathrm{CN})_{5} \mathrm{~N}(\mathrm{O}) \mathrm{SR}\right]^{(n+2)-}(\mathrm{RS}=$ cysteine and 2-aminoethanethiol) was accelerated up to 20 -fold when the $\mathrm{NH}_{2}$ group was protonated in both thiols [14]. On the other hand, little or no effect was observed for glutathione, in which the $\mathrm{NH}_{2}$ group lies far from the $\mathrm{S}-\mathrm{NO}$ bond [14].

In addition, Szaciłowski et al. [13] (see pathway (c) on Scheme 1) performed an embracing work considering kinetic, products analysis and DFT quantum calculations on respect to the reaction between NP and RSH (RSH = cysteine, glutathione, ethyl cysteinate and $\mathrm{N}$-acetylcysteine). These authors verified that the decomposition of the adduct $\left[\mathrm{Fe}(\mathrm{CN})_{5} \mathrm{~N}(\mathrm{O}) \mathrm{SR}\right]^{(n+2)-}$ is dependent on the chemical structure of the thiol. The presence of carboxylic groups on the thiols stabilizes the adduct, whereas the $-\mathrm{NH}_{2}$ groups destabilizes it [13]. However, if the $-\mathrm{NH}_{2}$ or carboxylic groups are blocked by esterification or acetylation for example, their influence on the stabilization of the adduct $\left[\mathrm{Fe}(\mathrm{CN})_{5} \mathrm{~N}(\mathrm{O}) \mathrm{SR}\right]^{(n+2)-}$ is suppressed [13]. These facts explain why the adduct formed when $\mathrm{RS}=\mathrm{N}$-acetylcysteine was the most stable in the series, whereas the adduct with RS = ethyl cysteinate was the less stable [13]. For the $\mathrm{N}$-acylated thiols, the stabilization of the adduct was ascribed to the formation of a six-membered ring (Scheme 2A), resulting in a strengthening of the $\mathrm{S}-\mathrm{N}$ bond [13]. In agreement, DFT studies have suggested a significantly positive charge $\left(\delta^{+}\right)$on the sulfur atoms of the nitrosothiol ligand in $\left[\mathrm{Fe}(\mathrm{CN})_{5} \mathrm{~N}(\mathrm{O}) \mathrm{SR}\right]^{(n+2)-}$, which is reasonable, considering the charge stabilization mechanism provided by the interaction of the sulfur atom with a 


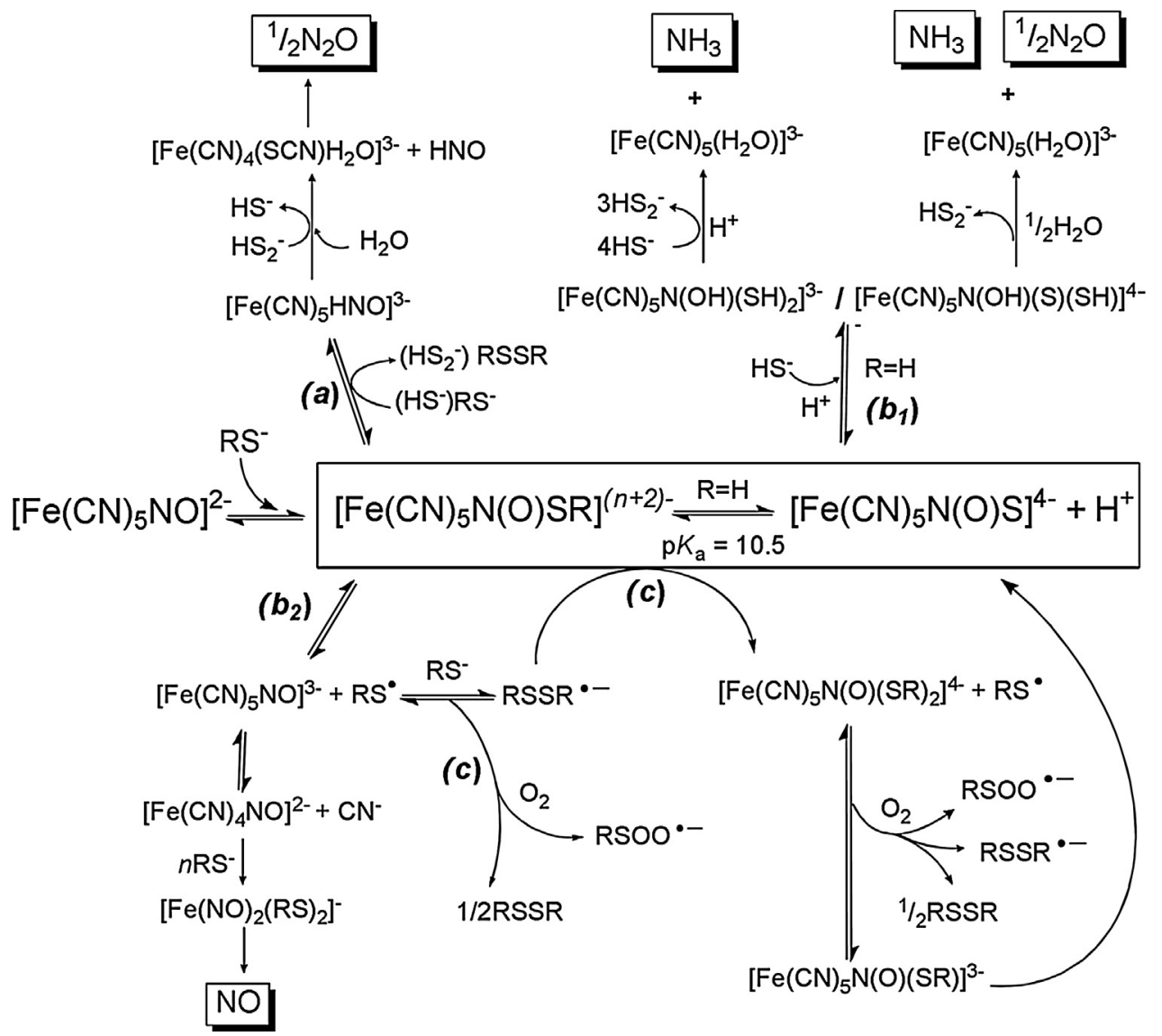

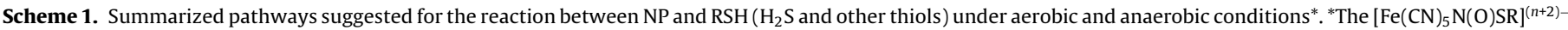

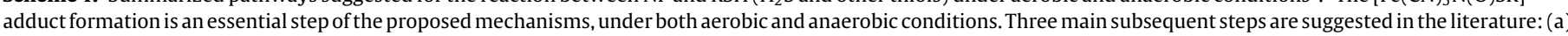

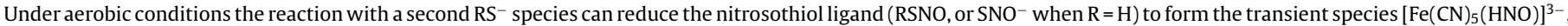

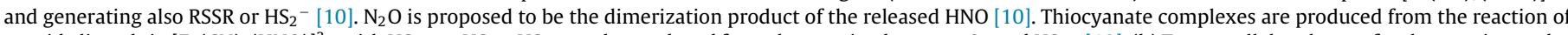

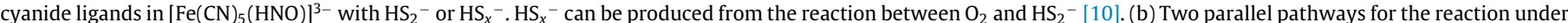

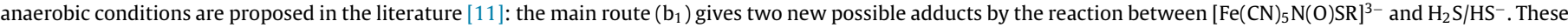

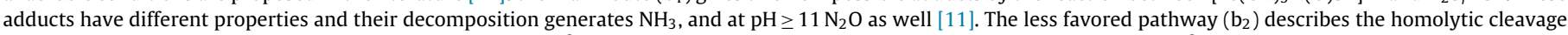

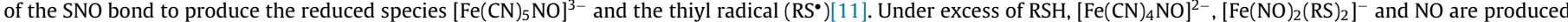

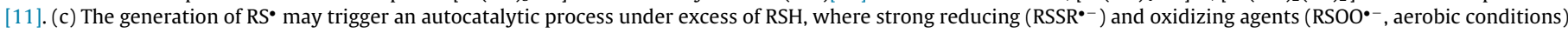
are produced [13].

carboxylic group (see Scheme 2A). On the other hand, similar calculations have suggested a quite negative charge on the sulfur atom (Scheme 2B) when it comes from the $\mathrm{HS}^{-}$as well as a positive charge on the nitrogen atom of the same moiety [11]. This changed significantly the electronic features of the adduct and consequently its stability in comparison to the complexes containing other $\mathrm{RS}^{-}$[13]. Kinetic data for the formation and decomposition of the $\left[\mathrm{Fe}(\mathrm{CN})_{5} \mathrm{~N}(\mathrm{O}) \mathrm{SH}\right]^{3-}$ adduct $\left(k_{\mathrm{HS}}-=190 \mathrm{M}^{-1} \mathrm{~s}^{-1}\right.$ and

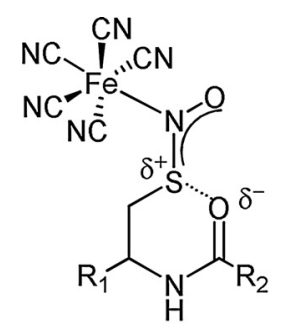

(A)<smiles>C=C=[N+]([S-])[P+]([O-])([O-])[N+](C#N)(C#N)C#N</smiles>

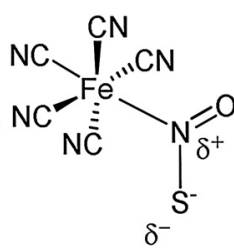

(B)
Scheme 2. (A) Proposed model for the stabilization of the $\mathrm{N}-\mathrm{S}$ bond due to the formation of a six-membered ring in the $\left[\mathrm{Fe}(\mathrm{CN})_{5} \mathrm{~N}(\mathrm{O}) \mathrm{SR}\right]^{(n+2)-}$ (adapted from Ref. [13]).(B) Acid-base equilibrium of the HSNO ligand in the $\left[\mathrm{Fe}(\mathrm{CN})_{5} \mathrm{~N}(\mathrm{O}) \mathrm{SH}\right]^{3-}$ adduct [11].
$k$-HS ${ }^{-}=0.30 \mathrm{~s}^{-1}$ ) [11] suggest that $\mathrm{HS}^{-}$is a poorer nucleophile than other thiols $\left(\mathrm{RS}^{-}\right)$. In addition, the acid-base equilibrium presumed for the $\left[\mathrm{Fe}(\mathrm{CN})_{5} \mathrm{~N}(\mathrm{O}) \mathrm{SH}\right]^{3-}$ and $\left[\mathrm{Fe}(\mathrm{CN})_{5} \mathrm{~N}(\mathrm{O}) \mathrm{S}\right]^{4-}$ (Scheme $2 \mathrm{~B}$ ) $[11,34]$ makes difficult the study of this system, once the protonated and deprotonated forms are suggested to have different reactivities toward $\mathrm{H}_{2} \mathrm{~S} / \mathrm{HS}^{-}[10,11,34]$.

More recently, the reaction between NP and $\mathrm{H}_{2} \mathrm{~S}$ was revisited under anaerobic conditions and in $\mathrm{pH}$ range of 8.5-12.5 by Olabe et al. [11], and new approaches on the mechanism and products analysis were raised by these authors. The initial addition of $\mathrm{HS}^{-}$to NP leads to an absorption increase at $570 \mathrm{~nm}$, which was ascribed to the $\left[\mathrm{Fe}(\mathrm{CN})_{5} \mathrm{~N}(\mathrm{O}) \mathrm{SH}\right]^{3-}$ adduct [11]. On basis of kinetic data and DFT calculations, a $\mathrm{p} K_{a}$ of 10.5 was suggested for the $\left[\mathrm{Fe}(\mathrm{CN})_{5} \mathrm{~N}(\mathrm{O}) \mathrm{SH}\right]^{3-}$ adduct, which coexists with the respective deprotonated form $\left[\mathrm{Fe}(\mathrm{CN})_{5} \mathrm{~N}(\mathrm{O}) \mathrm{S}\right]^{4-}$ in alkaline conditions [11]. According to the authors, $\left[\mathrm{Fe}(\mathrm{CN})_{5} \mathrm{~N}(\mathrm{O}) \mathrm{S}\right]^{4-}$ is responsible for an absorption band centered at $535 \mathrm{~nm}$ [11]. Both protonated and deprotonated species are proposed to be involved in two possible similar pathways, which lead to different products (see pathway $b_{1}$ on Scheme 1 ). The authors [11] assumed that both $\left[\mathrm{Fe}(\mathrm{CN})_{5} \mathrm{~N}(\mathrm{O}) \mathrm{SH}\right]^{3-}$ and $\left[\mathrm{Fe}(\mathrm{CN})_{5} \mathrm{~N}(\mathrm{O}) \mathrm{S}\right]^{4-}$ species can react with $\mathrm{HS}^{-}$(see pathway $\mathrm{b}_{1}$ on Scheme 1 ) to give the $\left[\mathrm{Fe}(\mathrm{CN})_{5} \mathrm{~N}(\mathrm{OH})(\mathrm{SH})_{2}\right]^{3-}$ and $\left[\mathrm{Fe}(\mathrm{CN})_{5} \mathrm{~N}(\mathrm{OH})(\mathrm{S})(\mathrm{SH})\right]^{4-}$ species, respectively. These latter species were proposed mainly based on 
theoretical approach and on the stoichiometry of the products formed. The nitrogen based products from the decomposition of these species were $\mathrm{NH}_{3}$ and $\mathrm{N}_{2} \mathrm{O}$ as presented in the pathway $\mathrm{b}_{1}$ on the Scheme 1 [11]. According to the authors, the production of $\mathrm{N}_{2} \mathrm{O}$ was observed only at $\mathrm{pH} \geq 11$ where the formation of $\left[\mathrm{Fe}(\mathrm{CN})_{5} \mathrm{~N}(\mathrm{OH})(\mathrm{S})(\mathrm{SH})\right]^{4-}$ would be favored [11]. The production of $\mathrm{N}_{2} \mathrm{O}$ was taken by the authors [11] as an indirect evidence of the formation of HNO because HNO dimerizes according the Eq. (6) with a rate constant of $8.0 \times 10^{6} \mathrm{M}^{-1} \mathrm{~s}^{-1}$ [27].

$\mathrm{HNO}+\mathrm{HNO} \rightarrow \mathrm{HONNOH} \rightarrow \mathrm{N}_{2} \mathrm{O}+\mathrm{H}_{2} \mathrm{O}$

Moreover, in a minor extent, an additional pathway is suggested to produce $\left[\mathrm{Fe}(\mathrm{CN})_{5} \mathrm{NO}^{\bullet}\right]^{3-}$ and $\mathrm{HS}_{2}{ }^{\cdot 2-}$, as shown generically for the reaction between NP and $\mathrm{RS}^{-}$(see pathway $\mathrm{b}_{2}$ on Scheme 1). This is a commonly accepted mechanism for the reaction between NP and excess of thiol, such as cysteine and glutathione [13]. As well known $[13,45]$, the species $\left[\mathrm{Fe}(\mathrm{CN})_{5} \mathrm{NO}^{\bullet}\right]^{3-}$ is involved in an equilibrium with $\left[\mathrm{Fe}(\mathrm{CN})_{4} \mathrm{NO}\right]^{2-}$ through cyanide labilization (see pathway $b_{2}$ on Scheme 1 ). This last species was characterized by a typical EPR spectrum obtained at room temperature $\left(25^{\circ} \mathrm{C}\right)$, which, according to the authors [11], decays to another spectrum assigned to the dinitrosyl complex $\left[\mathrm{Fe}(\mathrm{NO})_{2}(\mathrm{SH})_{2}\right]^{2-}$. This dinitrosyl complex would be the source of the observed NO released.

Some controversies about the mechanism proposed by Olabe [11] (pathways b1 and b2 on Scheme 1) were raised by the IvanovicBurmazovic's group [34]. The main points are regarding the deprotonated species $\left[\mathrm{Fe}(\mathrm{CN})_{5} \mathrm{~N}(\mathrm{O}) \mathrm{S}\right]^{4-}$, which was suggested by Olabe [11] to be formed from the initial adduct $\left[\mathrm{Fe}(\mathrm{CN})_{5} \mathrm{~N}(\mathrm{O}) \mathrm{SH}\right]^{3-}$, and the subsequent process ascribed to the decomposition of these adducts [34]. Ivanovic-Burmazovic's group [34] performed the reaction of NP with $\mathrm{H}_{2} \mathrm{~S}$ at $\mathrm{pH} 7.4$ (under anaerobic conditions) and verified by electronic spectroscopy similar results to that reported by Olabe [11] at $\mathrm{pH} 10.4$. This would be inconsistent with the suggested acid-base equilibrium ( $\mathrm{p} K_{a}$ 10.5) between the species $\left[\mathrm{Fe}(\mathrm{CN})_{5} \mathrm{~N}(\mathrm{O}) \mathrm{SH}\right]^{3-}$ and $\left[\mathrm{Fe}(\mathrm{CN})_{5} \mathrm{~N}(\mathrm{O}) \mathrm{S}\right]^{4-}$ (Scheme 1) [11]. Ivanovic-Burmazovic [34] assumed, based on the $\mathrm{p} K_{a} 10.5$ [11], that at pH 7.4 only the $\left[\mathrm{Fe}(\mathrm{CN})_{5} \mathrm{~N}(\mathrm{O}) \mathrm{SH}\right]^{3-}$ form would be present, being this species the one associated with the absorption band at $535 \mathrm{~nm}$, and not at $570 \mathrm{~nm}$ as ascribed previously [11].

In a subsequent work, Ivanovic-Burmazovic's group [10] investigated the reaction between NP and $\mathrm{H}_{2} \mathrm{~S}$ under physiological conditions (aerobic conditions at $\mathrm{pH} 7.4$, see pathway (a) on Scheme 1). Based on different techniques and experiments (chemical and biological assays), the authors provided evidence that $\mathrm{HNO}$ is the direct product of the reaction between $\left[\mathrm{Fe}(\mathrm{CN})_{5} \mathrm{NO}\right]^{2-}$ and $\mathrm{H}_{2} \mathrm{~S}$ [10]. The proposed mechanism in this case suggests that the reaction of $\left[\mathrm{Fe}(\mathrm{CN})_{5} \mathrm{~N}(\mathrm{O}) \mathrm{SH}\right]^{3-}$ with another molecule of $\mathrm{HS}^{-}$gives $\mathrm{N}_{2} \mathrm{O}$ as final product (pathway (a) on Scheme 1) [10]. Similarly to Olabe et al. [11], these authors assumed that $\mathrm{N}_{2} \mathrm{O}$ was produced from the dimerization of HNO (Eq. (6)). Although Ivanovic-Burmazovic et al. [10] does not cite the formation of a second adduct, like the mechanism proposed by Olabe [11] (compare the pathways $\left(b_{1}\right)$ and (a) on Scheme 1 ), the transient species $\left[\mathrm{Fe}(\mathrm{CN})_{5}(\mathrm{HNO})\right]^{3-}$ is indicated as the direct product from the reduction of the $\left[\mathrm{Fe}(\mathrm{CN})_{5} \mathrm{~N}(\mathrm{O}) \mathrm{SH}\right]^{3-}$ adduct by $\mathrm{HS}^{-}$[10]. Up to this point the aerobic condition used in the experiments performed by Ivanovic-Burmazovic's group [10,34] does not seem to have much influence in the decomposition of the $\left[\mathrm{Fe}(\mathrm{CN})_{5} \mathrm{~N}(\mathrm{O}) \mathrm{SH}\right]^{3-}$ adduct, at least not in terms of the main products formed $\left(\mathrm{N}_{2} \mathrm{O}\right)$ when compared with Olabe's group (anaerobic conditions) [11]. However, this reasoning is only a rough and qualitative comparison since, despite of the presence or absence of $\mathrm{O}_{2}$, the studies were performed in a quite different $\mathrm{pH}$ range $[10,11,34]$. Certainly a contribution provided by the study of Ivanovic-Burmazovic $[10,34]$ to the mechanism of the reaction between NP and $\mathrm{HS}^{-}$is the assignment of the band at $575 \mathrm{~nm}$ to the thiocyanate complex. This absorption was originally [11] ascribed to the $\left[\mathrm{Fe}(\mathrm{CN})_{5} \mathrm{~N}(\mathrm{O}) \mathrm{SH}\right]^{3-}$ adduct. The thiocyanate species $\left[\mathrm{Fe}(\mathrm{CN})_{4}(\mathrm{SCN})\left(\mathrm{H}_{2} \mathrm{O}\right)\right]^{3-}$ would be formed during the reaction of polysulfides $\left(\mathrm{HS}_{2}{ }^{-}\right.$or $\left.\mathrm{HS}_{x}{ }^{-}\right)$with cyanide ligands [10]. The presence of $\mathrm{O}_{2}$ was associated by the authors with a catalytic process which promoted the conversion of $\mathrm{HS}_{2}{ }^{-}$in to $\mathrm{HS}_{x}{ }^{-}$ in the presence of excess of $\mathrm{H}_{2} \mathrm{~S}$ [10]. According to the authors this process can yield the total conversion of the cyanide ligands into thiocyanate giving the $\left[\mathrm{Fe}(\mathrm{SCN})_{5}\left(\mathrm{H}_{2} \mathrm{O}\right)\right]^{3-}$ complex [10].

The recent propositions $[10,34]$ for the reactivity of $\left[\mathrm{Fe}(\mathrm{CN})_{5} \mathrm{~N}(\mathrm{O}) \mathrm{SH}\right]^{3-}$ are accurate and based on different techniques. However, the diversity of products suggested in these reactions appears to be strongly related with the reactivity of the cyanide ligand [10]. In this aspect, trans- $\left[\mathrm{Ru}\left(\mathrm{NH}_{3}\right)_{4}(\mathrm{~L})(\mathrm{NO})\right]^{3+}$, which contains inert $\mathrm{NH}_{3}$ equatorial ligands [33,35,39], can provide better structural conditions for the systematic study of reactions involving $\mathrm{OH}^{-}, \mathrm{S}$ - and $\mathrm{N}$-binding nucleophiles. Moreover, these ruthenium nitrosyl tetraammines have been studied as a model of nitric oxide donors [33,35,39,46-48], and some of them presented activity in different biological assays (vasodilatation [49], Chagas' disease [50-52], Leishmaniasis [53], cancer [54], tuberculosis [55], anti-inflammatory and analgesic [56]). The next section discusses some important aspects of the chemistry and reactivity of ruthenium nitrosyl ammine complexes with nucleophiles and also makes comparisons to other ruthenium systems and the nitroprusside ion.

\subsection{Nucleophilic addition in ruthenium nitrosyl ammines}

More recently, the redox reactions of ruthenium nitrosyl complexes, such as $\left[(\mathrm{L})_{5} \mathrm{Ru}(\mathrm{NO})\right]^{n}$, with thiols (i.e., cysteine and glutathione) have been described as a sequence of additions of the deprotonated thiols $\left(\mathrm{RS}^{-}\right)$on the nitrosonium $\left(\mathrm{NO}^{+}\right)$ligand [37] (Eqs. (7) and (8)). These reactions were largely based on the addition of $\mathrm{OH}^{-}$and $\mathrm{HS}^{-}$on $\left[\mathrm{Fe}(\mathrm{CN})_{5}(\mathrm{NO})\right]^{2-}$ (Eqs. (2)-(5)).

$$
\begin{aligned}
& {\left[(\mathrm{L})_{5} \mathrm{Ru}(\mathrm{NO})\right]^{n}+\mathrm{RS}^{-} \rightleftharpoons\left[(\mathrm{L})_{5} \operatorname{RuN}(\mathrm{O}) \mathrm{SR}\right]^{n-1}} \\
& {\left[(\mathrm{~L})_{5} \operatorname{RuN}(\mathrm{O}) \mathrm{SR}\right]^{n-1}+\mathrm{RS}^{-} \rightleftharpoons\left[(\mathrm{L})_{5} \operatorname{RuN}(\mathrm{O})(\mathrm{SR})_{2}\right]^{n-2}}
\end{aligned}
$$

The first step is a fast and reversible reaction between the metal complex and $\mathrm{RS}^{-}$species, yielding the $\left[(\mathrm{L})_{5} \mathrm{RuN}(\mathrm{O}) \mathrm{SR}\right]^{n-1}$ adduct (Eq. (7)) analogous to the formation of $\left[\mathrm{Fe}(\mathrm{CN})_{5} \mathrm{~N}(\mathrm{O}) \mathrm{SR}\right]^{(n+2)-}$ (Eq. (2)). The authors proposed the sequential formation of a second species, $\left[(\mathrm{L})_{5} \mathrm{RuN}(\mathrm{O})(\mathrm{SR})_{2}\right]^{n-2}$, which is reversible and a dependent reaction on the concentration of the thiol [RS ${ }^{-}$] (Eq. (8)) $[37,38]$. This second step (Eq. (8)) is slower than the first (Eq. (7)), see Table 3, because the $[\mathrm{RuN}(\mathrm{O}) \mathrm{SR}]$ moiety presents a smaller electrophilicity than the initial $\left[\mathrm{RuNO}^{+}\right]$moiety [37]. The proposition of the formation of $\left[(\mathrm{L})_{5} \mathrm{RuN}(\mathrm{O})(\mathrm{SR})_{2}\right]^{n-2}$ was mainly based on the transnitrosylation reaction suggested for thiols and nitrosothiols [57-60], as illustrated in Scheme 3A. In this reaction, an intermediate species containing two thiol groups binding to the NO moiety is proposed (Scheme $3 \mathrm{~A}$ ).

In that concern, kinetic studies have been carried out in vitro with proteins (human and bovine serum albumin) and lowmolecular-weight thiols (S-nitrosoglutathione, S-nitrosocysteine and S-nitroso-N-acetyl-D,L-penicillamine) [62]. The calculated rate constants for these reactions (Scheme $3 \mathrm{~A}$ ) are in the range of $10^{3}-10^{7} \mathrm{M}^{-1} \mathrm{~s}^{-1}[62]$ and are the highest values associated with the low-molecular-weight thiols. The transnitrosylation reaction (Scheme 3A) is the preferential pathway. However, the detection of disulfide species, RSSR (including mixed disulfides) and HNO (indirectly detected by the identification of $\mathrm{N}_{2} \mathrm{O}$ and other nitrogen species) suggests a parallel reaction that would occur via a S-binding nucleophilic attack, as illustrated in Scheme 3B [57]. Indeed, $\mathrm{N}_{2} \mathrm{O}, \mathrm{NH}_{3}, \mathrm{NH}_{2} \mathrm{OH}$, and the respective sulfonamide $\left(\mathrm{RS}(\mathrm{O}) \mathrm{NH}_{2}\right)$ (see Scheme 5) have been identified in these studies as 


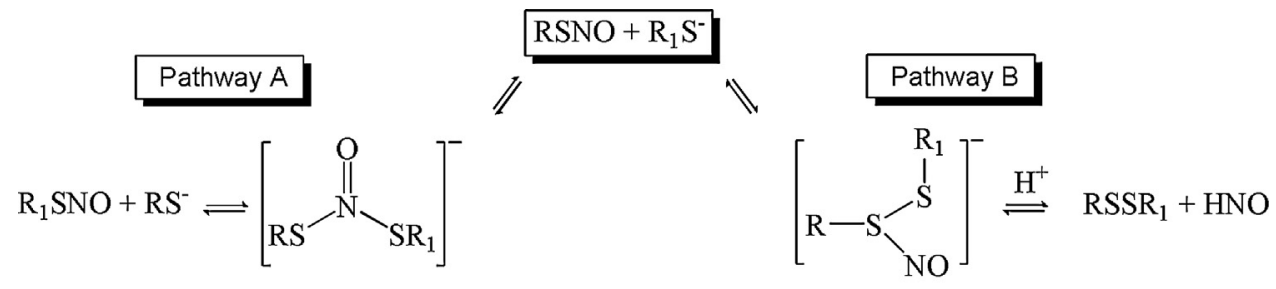

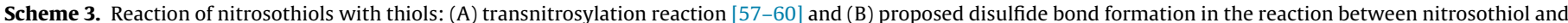
thiol [61].

Table 1

Calculated bond distances $(\AA)$ and natural bond order (NBO) charges for optimized structures of free (non-coordinated) and coordinated thiols $[\mathrm{MN}(\mathrm{O}) \mathrm{SR}]^{n}$

\begin{tabular}{|c|c|c|c|c|c|c|}
\hline \multirow[t]{2}{*}{ Compound } & \multicolumn{3}{|c|}{ Distances $(\AA)$} & \multicolumn{3}{|l|}{ NBO charge ${ }^{*}$} \\
\hline & $\mathrm{M}-\mathrm{N}$ & $\mathrm{S}-\mathrm{N}$ & $\mathrm{N}-\mathrm{O}$ & $\mathrm{S}$ & $\mathrm{N}$ & $\mathrm{O}$ \\
\hline$\left[\mathrm{Fe}(\mathrm{CN})_{5} \mathrm{~N}(\mathrm{O}) \mathrm{SH}\right]^{3-\mathrm{a}}$ & 1.787 & 2.136 & 1.210 & -0.385 & 0.228 & -0.277 \\
\hline$\left[\mathrm{Fe}(\mathrm{CN})_{5} \mathrm{~N}(\mathrm{O}) \mathrm{S}\right]^{4-\mathrm{a}}$ & 1.970 & 1.864 & 1.248 & -0.520 & 0.059 & -0.375 \\
\hline$\left[\mathrm{Fe}(\mathrm{CN})_{5} \mathrm{~N}(\mathrm{O}) \mathrm{SCH}_{3}\right]^{3-\mathrm{b}}$ & 1.759 & 2.244 & 1.220 & -0.109 & 0.284 & -0.318 \\
\hline trans- $\left[\mathrm{IrCl}_{5} \mathrm{~N}(\mathrm{O}) \mathrm{SCH}_{3}\right]^{2-\mathrm{b}}$ & 1.939 & 1.939 & 1.243 & 0.263 & 0.035 & -0.308 \\
\hline trans- $\left[\mathrm{IrCl}_{4}\left(\mathrm{CH}_{3} \mathrm{CN}\right) \mathrm{N}(\mathrm{O}) \mathrm{SCH}_{3}\right]^{2-\mathrm{b}}$ & 1.854 & 1.854 & 1.240 & 0.403 & 0.014 & -0.269 \\
\hline trans- $\left[\mathrm{Ru}\left(\mathrm{NH}_{3}\right)_{4}(4-\mathrm{pic}) \mathrm{N}(\mathrm{O}) \mathrm{SR}\right]^{2+c}$ & 2.002 & 1.831 & 1.222 & $0.432(0.427)$ & $0.015(-0.033)$ & $-0.357(-0.379)$ \\
\hline trans $-\left[\mathrm{Ru}\left(\mathrm{NH}_{3}\right)_{4} \mathrm{P}(\mathrm{OEt})_{3} \mathrm{~N}(\mathrm{O}) \mathrm{SR}\right]^{2+\mathrm{c}}$ & 2.118 & 1.813 & 1.214 & $0.472(0.469)$ & $0.017(-0.053)$ & $-0.323(-0.341)$ \\
\hline trans- $\left[\mathrm{Ru}\left(\mathrm{NH}_{3}\right)_{4}(4-\mathrm{pic})(\mathrm{NO})\right]^{3+\mathrm{c}}$ & 1.808 & - & 1.116 & - & $0.434(0.362)$ & $0.016(-0.001)$ \\
\hline trans $-\left[\mathrm{Ru}\left(\mathrm{NH}_{3}\right)_{4} \mathrm{P}(\mathrm{OEt})_{3}(\mathrm{NO})\right]^{3+c}$ & 1.834 & - & 1.117 & - & $0.439(0.333)$ & $0.010(-0.007)$ \\
\hline Cysteine $^{c}$ & - & - & - & $-0.775(-0.774)$ & - & - \\
\hline S-nitroso-cysteine ${ }^{c}$ & - & 1.849 & 1.181 & $0.333(0.334)$ & $0.015(0.013)$ & $-0.272(-0.270)$ \\
\hline
\end{tabular}

a Ref. [11].

b $\mathrm{SCH}_{3}{ }^{-}=$methylthiol Ref. [32].

c $\mathrm{RS}^{-}=$cysteine Ref. [63].

* The values in parentheses were obtained by using NBO6. The NBO 6.0 program [Ref. 131] overcomes the limitations observed in older versions, giving more consistent results.

products of the reaction between $\mathrm{HNO}$ and the reduced thiol (RSH) [61].

The reactions shown in Eqs. (7) and (8) were proposed in the literature [37] to explain the formation of disulfides (RSSR) and $\mathrm{N}_{2} \mathrm{O}$ after the mixing of ruthenium nitrosyl complexes $\left[(\mathrm{L})_{5} \mathrm{Ru}(\mathrm{NO})\right]^{n}$ ( $\mathrm{L}=$ polypyridine, pyrazine, $\mathrm{NH}_{3}$ and EDTA) with cysteine [37]. However, in this case, the authors [37] only assume the attack of the second thiol (Eq. (8)) on the nitrogen atom of the nitrosonium ligand (similar to the transnitrosylation reaction in Scheme $3 \mathrm{~A}$ ) and do not consider the intermediate species - analogous to that shown in Scheme 3B - in the case of the ruthenium complexes [37]. DFT calculations on trans- $\left[\mathrm{Ru}\left(\mathrm{NH}_{3}\right)_{4}(\mathrm{~L}) \mathrm{N}(\mathrm{O}) \mathrm{SR}\right]^{2+}(\mathrm{L}=4$-picoline or $\mathrm{P}(\mathrm{OEt})_{3}$ (triethylphosphite) and $\mathrm{RS}=$ cysteine) predicted a more positive charge on the sulfur atom of the coordinated RSNO molecule than on the free one (Table 1) [63] (Of note, this tendency was also observed for NBO6 charges). Furthermore, this positive charge on the sulfur atom of the RSNO ligand is substantially greater than the charge calculated for the nitrogen atom, as shown in Table 1. This trend was not observed for $\left[\mathrm{Fe}(\mathrm{CN})_{5} \mathrm{~N}(\mathrm{O}) \mathrm{SR}\right]^{(n+2)-}$ when $\mathrm{RS}^{-}=\mathrm{HS}^{-}\left(\mathrm{S}^{2-}\right)$ and $\mathrm{CH}_{3} \mathrm{~S}^{-}$(see Table 1). However, Szaciłowski et al. [13] found that this is likely not true for $\mathrm{RS}^{-}=\mathrm{N}$-acetylcysteine, ethyl cysteinate, cysteine and glutathione where Mulliken charge analysis gave positive values for the charge of the respective sulfur atoms of $\left[\mathrm{Fe}(\mathrm{CN})_{5} \mathrm{~N}(\mathrm{O}) \mathrm{SR}\right]^{(n+2)-}$ $(+0.30$ in average, data not shown in Table 1$)$.

The positive charge on the sulfur atom of the $[\mathrm{MN}(\mathrm{O}) \mathrm{SR}]^{n}$ moiety $(\mathrm{M}=\mathrm{Fe}$ or $\mathrm{Ru}, \mathrm{RS}=$ thioamine acid $)$ has been interpreted as a plausible factor suggesting that the sulfur atom in the coordinated S-nitrosothiol acts as a preferential electrophilic site for the addition of a second thiol. Doctorovich et al. [32] performed experimental and theoretical studies on the nitrosothiols derived from an iridium complex (trans- $\left[\mathrm{IrCl}_{4}\left(\mathrm{CH}_{3} \mathrm{CN}\right) \mathrm{N}(\mathrm{O}) \mathrm{SR}\right]^{n-}$ ) and from the nitroprusside ion $\left(\left[\mathrm{Fe}(\mathrm{CN})_{5} \mathrm{~N}(\mathrm{O}) \mathrm{SR}\right]^{n-}\right)(\mathrm{RS}=$ mercaptosuccinic acid, benzyl thiol, phenyl thiol, N-acetyl-L-cysteine, L-cysteine ethyl ester, and glutathione) [32]. The results obtained are in agreement with the calculations predicting a more positive charge on the sulfur atom than on the nitrogen atom of trans$\left[\mathrm{Ru}\left(\mathrm{NH}_{3}\right)_{4}(\mathrm{~L}) \mathrm{N}(\mathrm{O}) \mathrm{SR}\right]^{2+}$ (Table 1). Doctorovich et al. [32] have also described the synthesis and stability of the respective nitrosothiol complexes as a function of the nature of the RS group. The coordinated S-nitrosothiol is more stable than the free one based on its decomposition [32]. The DFT calculations were performed on structures of trans- $\left[\mathrm{IrCl}_{4}(\mathrm{~L}) \mathrm{N}(\mathrm{O}) \mathrm{SR}\right]^{n-}\left(\mathrm{L}=\mathrm{Cl}^{-}\right.$or $\left.\mathrm{CH}_{3} \mathrm{CN}\right)$ and $\left[\mathrm{Fe}(\mathrm{CN})_{5} \mathrm{~N}(\mathrm{O}) \mathrm{SR}\right]^{3-}$, where $\mathrm{RS}^{-}=$methylthiol as a model thiol [32]. The calculated bond distances $(\AA)$ and natural bond order (NBO) charges reported by these authors are listed in Table 1 and compared to those reported for trans $-\left[\mathrm{Ru}\left(\mathrm{NH}_{3}\right)_{4}(\mathrm{~L}) \mathrm{N}(\mathrm{O}) \mathrm{SR}\right]^{2+}$ ( $\mathrm{L}=4$-picoline and $\mathrm{P}(\mathrm{OEt})_{3}$; $\mathrm{RS}^{-}=$cysteine) [63].

A similar trend was observed for iridium and ruthenium species regarding both the bond distances and charges on the $[\mathrm{M}-\mathrm{N}(\mathrm{O}) \mathrm{SR}]$ moiety (Table 1$)$. The negative charge of the free thiol $\left(\mathrm{RS}^{-}\right)$, as calculated for cysteine and expected for other thiols such as methylthiol model $\left(\mathrm{CH}_{3} \mathrm{~S}^{-}\right)$, should be significantly distributed on the nitrogen atom and the metal center $\left(\mathrm{Ru}^{\mathrm{II}}\right.$ and $\left.\mathrm{Ir}^{\mathrm{III}}\right)$ when $\mathrm{RS}^{-}$is coordinated to the complexes (compared to the charge of the sulfur atom in free and coordinated cysteine, see Table 1 ). However, this was not the case reported for $\left[\mathrm{Fe}(\mathrm{CN})_{5} \mathrm{~N}(\mathrm{O}) \mathrm{SR}\right]^{3-}\left(\mathrm{RS}^{-}=\mathrm{CH}_{3} \mathrm{~S}^{-}\right.$and HS $^{-}$) $[11,32]$, in which the sulfur atom presents a negative charge. This negative charge was likely due to the lower stabilization of the coordinated nitrosothiol by the $\left[\mathrm{Fe}(\mathrm{CN})_{5}\right]$ moiety compared with the $\mathrm{Ru}^{\mathrm{II}}$ and Ir III systems. Indeed, Doctorovich et al. [32] described that in aqueous solution the iridium nitrosothiol complexes are more stable ( $t_{1 / 2}$ up to 14 days) than the iron nitrosothiol complexes $\left(1.16<t_{1 / 2}<2166 \mathrm{~min}\right)$ [32]. Because the iridium complexes have already been isolated and based on the similarity of the theoretical results for the iridium and ruthenium ammine complexes 


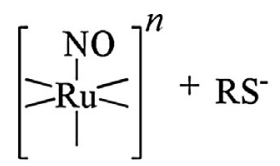

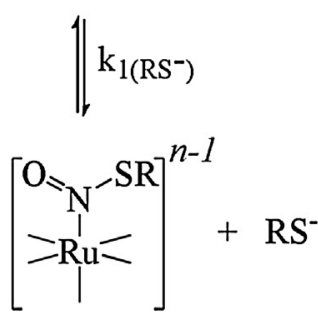<smiles>C=CC=CC=[W]</smiles>

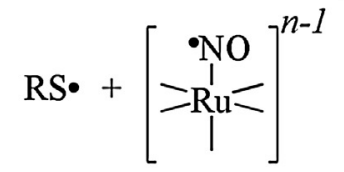

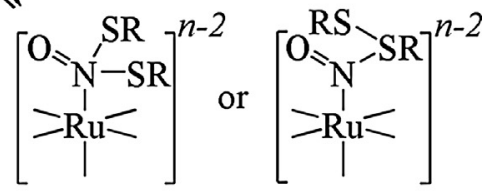

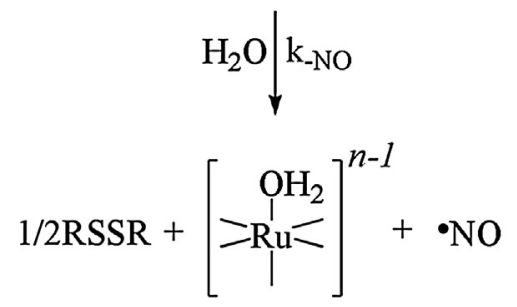<smiles></smiles>

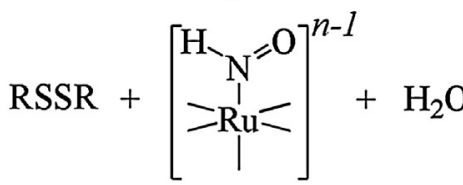

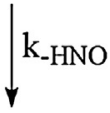

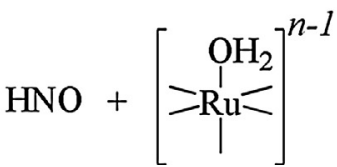

Scheme 4. Proposed competitive pathways for the NO and HNO formation from the addition of RS- to ruthenium nitrosyl complexes [37,38,63,69].

(Table 1), the complexes of ruthenium can likely also be isolated. Overall, the more positive charge on the sulfur atom of the trans$\left[\mathrm{Ru}\left(\mathrm{NH}_{3}\right)_{4}(\mathrm{~L}) \mathrm{N}(\mathrm{O}) \mathrm{SR}\right]^{n+}$ and trans- $\left[\mathrm{IrCl}_{4}(\mathrm{~L}) \mathrm{N}(\mathrm{O}) \mathrm{SR}\right]^{n-}$ complexes can be a key factor to understanding the formation and nature of the suggested $\left[(\mathrm{L})_{5} \mathrm{MN}(\mathrm{O})(\mathrm{SR})_{2}\right]^{n-2}$ species (Eq. (8)).

To date and to the best of our knowledge, structures of the type $\left[\mathrm{RuN}(\mathrm{O})(\mathrm{SR})_{2}\right]$ have not yet been isolated or theoretically studied. Nevertheless, they are suggested as the intermediate species formed in the reaction between the [RuN(O)SR] adduct and RS- (Eq. (8) and Scheme 4). However, there is no strong evidence regarding

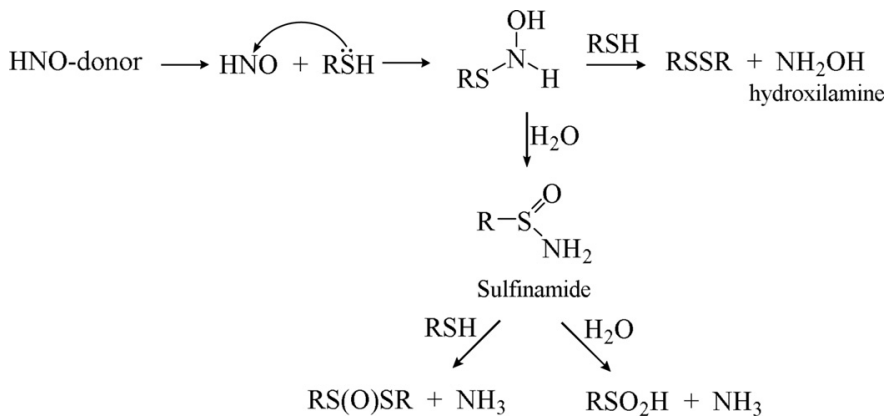

Scheme 5. Nitrogen products formed in the reaction between HNO and thiol (RSH) $[61,84,86]$. the preferential site for the addition of the second thiol: either the nitrogen or sulfur atom of the $[\operatorname{RuN}(\mathrm{O}) \mathrm{SR}]$ moiety. Theoretical studies on the intermediate species $[\mathrm{RSN}(\mathrm{O}) \mathrm{SR}]^{-}$(Scheme $3 \mathrm{~A}$ ) and $[\mathrm{RS}(\mathrm{NO}) \mathrm{SR}]^{-}$(Scheme $3 \mathrm{~B}$ ) have been performed by considering the free nitrosothiol, and the energies related to each possible pathway have been calculated. The calculations demonstrated that both pathways (Scheme $3 \mathrm{~A}$ and $\mathrm{B}$ ) are energetically viable, although the first one (Scheme 3A) has been considered slightly favored $[57,64]$. In fact, in the case of nitrosothiol complexes, a similar trend should not necessarily be expected. The positive charge on the sulfur atom of the complexes (see Table 1) suggests it as a plausible electrophilic site leading the reaction to proceed via a pathway similar to Scheme 3B.

Although the nature of the proposed intermediate in Eq. (8) is still unresolved, the literature [37] suggests $\left[(\mathrm{L})_{5} \mathrm{RuN}(\mathrm{O})(\mathrm{SR})_{2}\right]^{n-2}$ as the precursor of the $\left[(\mathrm{L})_{5} \mathrm{Ru}(\mathrm{HNO})\right]^{n-1}$ species. This latter species is proposed to be the HNO donor due to the high lability of the nitroxyl ligand [37]. The experimental evidence of the formation of the $\left[(\mathrm{L})_{5} \mathrm{Ru}(\mathrm{HNO})\right]^{n-1}$ species suggests that the HNO ligand is more weakly coordinated to the ruthenium(II) center than the NO• species $[36,40,65]$. In this regard, HNO was recently proposed to be formed through a two-electron chemical or electrochemical reduction of trans- $\left[\mathrm{Ru}\left(\mathrm{NH}_{3}\right)_{4} \mathrm{P}(\mathrm{III})(\mathrm{NO})\right]^{3+}(\mathrm{P}(\mathrm{III})=$ diethylphosphite and triethylphosphite) $[36,40]$. In this case, the nitroxyl ligand 
was rapidly aquated $\left(k_{-\mathrm{HNO}} \geq 0.98 \mathrm{~s}^{-1}\right)$ from the coordination sphere, and the identification of $\mathrm{N}_{2} \mathrm{O}$ was used as evidence of HNO formation. The rapid labilization of HNO from the coordinated sphere is expected to occur, although stable HNO derivatives in aqueous solution and even isolated complexes are known (i.e., $\left[\mathrm{Fe}(\mathrm{CN})_{5}(\mathrm{HNO})\right]^{2-}[66],\left[\mathrm{Ru}\left(\mathrm{Me}_{3}[9] \mathrm{aneN}_{3}\right)(\mathrm{bpy})(\mathrm{HNO})\right]^{2+}$, $\mathrm{Me}_{3}$ [9] aneN $\mathrm{N}_{3}=1,4,7$-trimethyl-1,4,7-triazacyclononane [65], [Ru(ttp)(HNO)(1-MeIm)], ttp = tetratolylporphyrinato dianion, MeIm = methylimidazole) [67], [Ru(HNO)('py $\left.\left.{ }^{\mathrm{bu}} \mathrm{S}_{4}{ }^{\prime}\right)\right],{ }^{\prime} \mathrm{py}^{\mathrm{bu}} \mathrm{S}_{4}{ }^{\prime}=2,6-$ bis(2-mercapto-3,5-di-tert-butylphenylthio)dimethylpyridine [68]. However, the ruthenium nitroxyl complexes of the type $\left[(\mathrm{L})_{5} \mathrm{Ru}(\mathrm{HNO})\right]^{n-1}\left(\mathrm{~L}=\mathrm{NH}_{3}\right.$, bpy, $\left.\mathrm{CN}^{-}\right)$were proposed to be transient species formed during the reactions between several $\left[\mathrm{RuNO}^{+}\right]$ complexes and RS- [37].

Another report by Lopes et al. [38] described the kinetics and product analysis of the reaction between cis-[Ru(NO)(bpy) $\left.)_{2}(\mathrm{~L})\right]^{n+}$ and $\mathrm{RS}^{-}\left(\mathrm{L}=\right.$ imidazole $(\mathrm{imN})$ or sulfite $\left(\mathrm{SO}_{3}{ }^{2-}\right)$; $\mathrm{RS}^{-}=$cysteine or glutathione). Although the authors suggest the formation of an intermediate containing two $\mathrm{RS}^{-}$groups (cis$\left.\left[\mathrm{Ru}(\mathrm{bpy})_{2}(\mathrm{~L}) \mathrm{N}(\mathrm{O})(\mathrm{SR})_{2}\right]^{n}\right)$, NO, not HNO, was proposed as the product [38]. Because the cis-[Ru(bpy $\left.)_{2}(\mathrm{~L})\left(\mathrm{NO}^{\bullet}\right)\right]^{n}(\mathrm{~L}=\mathrm{imN}$ and $\mathrm{SO}_{3}{ }^{2-}$ ) species were characterized by EPR spectroscopy and free $\mathrm{NO}{ }^{\bullet}$ was detected using a NO electrode, the authors suggest that the reaction between cis- $\left[\mathrm{Ru}(\mathrm{NO})(\mathrm{bpy})_{2}(\mathrm{~L})\right]^{n+}$ and $\mathrm{RS}^{-}$does not lead to the formation of cis-[Ru(bpy $\left.)_{2}(\mathrm{~L})(\mathrm{HNO})\right]^{n}$ and thus does not release HNO [38].

In this context, despite the similarity of the $E_{\mathrm{NO}+/ \mathrm{NO}}{ }^{\bullet}$ couple for the cis-[Ru(NO)(bpy) $\left.)_{2}(\mathrm{~L})\right]^{n+}$ complexes in terms of structure and reduction potential (with $\mathrm{L}=\mathrm{SO}_{3}{ }^{2-}$ or imidazole [38] or $\mathrm{L}^{-} \mathrm{NO}_{2}{ }^{-}$, $\mathrm{Cl}^{-}$, or AcN [37], see Table 4 in Section 2.3), the reactions of these species with $\mathrm{RS}^{-}$lead to either NO [38] or HNO [37] under similar experimental conditions. In this regard, recently was reported $[53,69]$ both $\mathrm{NO}$ and $\mathrm{HNO}$ as products of the reaction between trans- $\left[\mathrm{Ru}\left(\mathrm{NH}_{3}\right)_{4} \mathrm{P}(\mathrm{OEt})_{3}(\mathrm{NO})\right]^{3+}$ and cysteine (pH 3.0-7.4) $[53,69]$. NO was reported as the major product in mild acidic conditions $(3.0 \leq \mathrm{pH} \leq 4.0)$, whereas HNO was suggested as the main product in solutions close to neutrality [69]. This difference was ascribed to the natural increase in $\mathrm{RS}^{-}$concentration with respect to RSH with increasing $\mathrm{pH}$. Indeed, the thiolate ion $\left(\mathrm{RS}^{-}\right)$is considered the reactive species of thiols [37], and its formation occurs in two situations: (i) from the acid-base equilibrium involving the deprotonation of the $-\mathrm{SH}$ group ( $\mathrm{p} K_{\mathrm{a}}$ 's 8.3 and 8.7 for cysteine and glutathione respectively) and (ii) at acidic $\mathrm{pH}$ according to the tautomeric equilibrium constants described in the literature [70-72]. Therefore, at a $\mathrm{pH}$ close to the $\mathrm{p} K_{a}$ of the $\mathrm{SH}$ group, the formation of the intermediate species containing two thiol molecules, trans$\left[\mathrm{Ru}\left(\mathrm{NH}_{3}\right)_{4} \mathrm{P}(\mathrm{OEt})_{3} \mathrm{~N}(\mathrm{O})(\mathrm{SR})_{2}\right]^{n}$, is favored [69]. This last effect is also observed when the $\left[\mathrm{RS}^{-}\right] /[\mathrm{RSH}]$ ratio increases at a given $\mathrm{pH}$. The dependence on the concentration of $\left[\mathrm{H}^{+}\right]$and $\left[\mathrm{RS}^{-}\right]$appears to be consistent with the equilibrium constants for the formation of the $\left[(\mathrm{L})_{5} \mathrm{RuN}(\mathrm{O}) \mathrm{SR}\right]^{n-1}$ and $\left[(\mathrm{L})_{5} \mathrm{RuN}(\mathrm{O})(\mathrm{SR})_{2}\right]^{n-2}$ species, as shown in Scheme 4 and by Eqs. (9) and (10).

The formation of NO and HNO in solution and their ratio would be dependent on the stability of the $\left[(\mathrm{L})_{5} \mathrm{RuN}(\mathrm{O}) \mathrm{RS}\right]^{n-1}$ and $\left[(\mathrm{L})_{5} \mathrm{RuN}(\mathrm{O})(\mathrm{RS})_{2}\right]^{n-2}$ species, respectively, for the ruthenium tetraammine systems [69]. In both cases, the $\left[\mathrm{RuH}_{2} \mathrm{O}\right]^{n}$ complex (Scheme 4) would be the final product and would be formed according to the rate in Eq. (11) [69].

$K_{1}=\frac{[\operatorname{RuN}(\mathrm{O}) \mathrm{SR}] \cdot\left[\mathrm{H}^{+}\right]}{[\operatorname{RuN}(\mathrm{O})] \cdot[\mathrm{RSH}]}$

$K_{2}=\frac{\left[\operatorname{RuN}(\mathrm{O})(\mathrm{SR})_{2}\right] \cdot\left[\mathrm{H}^{+}\right]}{[\mathrm{RuN}(\mathrm{O}) \mathrm{SR}] \cdot[\mathrm{RSH}]}$

$d \frac{\left[\mathrm{Ru}\left(\mathrm{H}_{2} \mathrm{O}\right)\right]}{d t}=k_{3}[\mathrm{RuN}(\mathrm{O}) \mathrm{SR}]+k_{4}\left[\operatorname{RuN}(\mathrm{O})(\mathrm{SR})_{2}\right]$

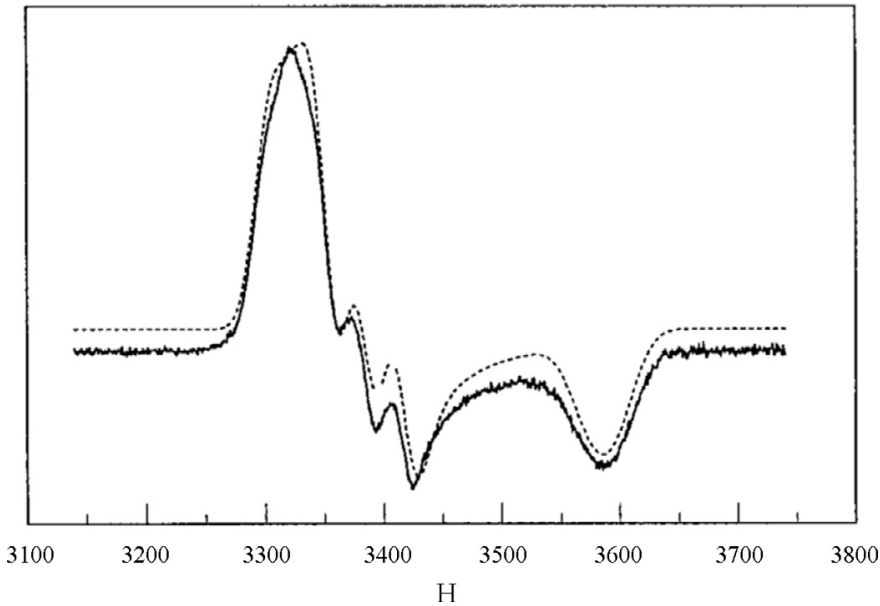

Fig. 1. EPR spectrum of a frozen solution of trans- $[\mathrm{Ru}(\mathrm{Cl})(\text { cyclam })(\mathrm{NO})]^{2+}$ in an ethylene glycol $+30 \% \mathrm{H}_{2} \mathrm{O}$ solution that was frozen after the addition of $\mathrm{Eu}^{2+}$. Considering the fast labilization of $\mathrm{Cl}^{-}$after reduction of trans- $[\mathrm{Ru}(\mathrm{Cl})(\operatorname{cyclam})(\mathrm{NO})]^{2+}$, the EPR signal is likely due to the complex trans- $\left[\mathrm{Ru}\left(\mathrm{H}_{2} \mathrm{O}\right)(\mathrm{cyclam}) \mathrm{NO}\right]^{2+}$. The dashed line is the simulated spectrum.

Source: Reprinted with permission from [73] Inorg. Chem., 2000, 39 (16), pp. 3577-3581. Copyright (2014) American Chemical Society.

The products of the reaction of trans- $\left[\mathrm{Ru}\left(\mathrm{NH}_{3}\right)_{4}(\mathrm{~L})(\mathrm{NO})\right]^{3+}(\mathrm{L}=4-$ picoline and $\left.\mathrm{P}(\mathrm{OEt})_{3}\right)$ with glutathione were verified to be the same as the products of the reaction with cysteine [63]. In particular, the reaction between trans- $\left[\mathrm{Ru}\left(\mathrm{NH}_{3}\right)_{4}(4 \text {-pic)(NO) }]^{3+}\right.$ and glutathione yields a signal profile characteristic of coordinated $\mathrm{NO}^{\bullet}$ in the EPR spectrum [63], similar to that described for cis-[Ru(bpy $)_{2}(\mathrm{~L})(\mathrm{NO} \bullet]^{n}$ $[38]$, trans- $\left[\mathrm{Ru}\left(\mathrm{H}_{2} \mathrm{O}\right)(\text { cyclam })\left(\mathrm{NO}^{\bullet}\right)\right]^{2+}[73]$ and other nitrosyl complexes $[63,74-76]$ (see Fig. 1 and Table 2).

The identification of free and coordinated $\mathrm{NO}^{\bullet}$ in these reactions (Fig. 1 and Table 2) suggests that the nucleophilic addition of $\mathrm{RS}^{-}$on these complexes should not necessarily only lead to the $\left[\operatorname{RuN}(\mathrm{O})(\mathrm{SR})_{2}\right]^{n-2}$ adduct species shown in Eq. (8). The formation of species such as $\left[(\mathrm{L})_{5} \mathrm{Ru}\left(\mathrm{NO}^{\bullet}\right)\right]^{n-1}$ is a strong evidence of the homolytic cleavage of the $\mathrm{S}-\mathrm{N}$ bond of the $\left[\mathrm{Ru}(\mathrm{L})_{5} \mathrm{~N}(\mathrm{O}) \mathrm{SR}\right]^{n-1}$ adduct (Eq. (7), Scheme 4). This pathway has been indicated for the reaction between $\left[\mathrm{Fe}(\mathrm{CN})_{5}(\mathrm{NO})\right]^{2-}$ and $\mathrm{RS}^{-}$[37]. The $\left[\mathrm{Fe}(\mathrm{CN})_{5}(\mathrm{NO} \bullet)\right]^{3-}$ species was detected by EPR spectroscopy; moreover, $\left[\mathrm{Fe}(\mathrm{CN})_{4}\left(\mathrm{NO}^{\bullet}\right)\right]^{2-}$ has been isolated from the equilibrium in Eq. (12), and its crystalline structure was studied by X-ray diffraction [45].

$\left[\mathrm{Fe}(\mathrm{CN})_{5}\left(\mathrm{NO}^{\bullet}\right)\right]^{3-} \rightleftharpoons\left[\mathrm{Fe}(\mathrm{CN})_{4}\left(\mathrm{NO}^{\bullet}\right)\right]^{2-}+\mathrm{CN}^{-}$

The set of considerations described above allows for the proposition of an adapted sequence of reactions that explains the formation of the products identified in the reactions between nitrosyl complexes and thiols in a more adequate fashion (Scheme 4). The possible products originated from the intermediate $\left[(\mathrm{L})_{5} \mathrm{RuN}(\mathrm{O}) \mathrm{SR}\right]^{n-1}$ species will be associated with the chemical features of the $[\mathrm{RuN}(\mathrm{O}) \mathrm{SR}]$ moiety promoted by other ligands (L). The modulation of the coordination sphere of these nitrosyl complexes can provide more or less stability to this moiety. Indeed, although most reports describe species of the type $\left[(\mathrm{L})_{5} \mathrm{RuN}(\mathrm{O}) \mathrm{SR}\right]^{n-1}$ with a half-life of milliseconds to seconds $[13,14,37]$, examples of kinetically and thermodynamically stable compounds formed after the nucleophilic addition of nitrosyl complexes are known: cis-[ $\left.\mathrm{Ru}^{\mathrm{II}} \mathrm{Cl}(\mathrm{bpy})_{2} \mathrm{~N}(\mathrm{O}) \mathrm{SO}_{3}\right]$ [9] and trans- $\mathrm{K}\left[\mathrm{Ir}^{\mathrm{III}} \mathrm{Cl}_{4}\left(\mathrm{CH}_{3} \mathrm{CN}\right) \mathrm{N}(\mathrm{O}) \mathrm{SCH}_{2} \mathrm{Ph}\right]$ [77].

Scheme 4 presents NO, HNO and the aquo complex as the main products formed in the reaction of thiols with ruthenium nitrosyl complexes. The aquo complexes are generally detected by cyclic voltammetry and UV-vis spectroscopy $[37,69]$. Nitric oxide has also 
Table 2

$g$ values and ${ }^{14} \mathrm{~N}$ hyperfine constants (both in Gauss) for reduced* $\left(\left[\mathrm{M}\left(\mathrm{NO}{ }^{\bullet}\right)\right]\right)$ nitrosyl complexes.

\begin{tabular}{|c|c|c|c|c|c|c|c|}
\hline Complex ${ }^{*}$,\# & $g_{(1)}$ & $g_{(2)}$ & $g_{(3)}$ & $A_{(1)}$ & $A_{(2)}$ & $A_{(3)}$ & Ref \\
\hline$\left[\mathrm{Fe}(\mathrm{CN})_{5} \mathrm{NO}\right]^{3-\mathrm{a}}$ & 1.99 & 1.99 & 1.92 & n.a & 28 & n.a & {$[74,75]$} \\
\hline$\left[\mathrm{Ru}(\mathrm{CN})_{5} \mathrm{NO}\right]^{3-\mathrm{b}}$ & 2.004 & 2.002 & 1.870 & n.o & 38 & n.o & [74] \\
\hline$\left[\mathrm{Os}(\mathrm{CN})_{5} \mathrm{NO}\right]^{3-\mathrm{b}}$ & 1.959 & 1.931 & 1.634 & n.o & 35 & n.o & [74] \\
\hline trans $-\left[\mathrm{Ru}\left(\mathrm{H}_{2} \mathrm{O}\right)(\text { cyclam }) \mathrm{NO}\right]^{2+c}$ & 2.035 & 1.995 & 1.883 & 17 & 32.1 & 15 & [73] \\
\hline trans $-\left[\mathrm{Ru}(\mathrm{Cl})(\mathrm{depe})_{2} \mathrm{NO}\right]^{2+\mathrm{d}}$ & 2.010 & 1.984 & 1.888 & 18 & 35 & 19 & [73] \\
\hline$c i s-\left[\mathrm{Ru}(\mathrm{bpy})_{2}\left(\mathrm{SO}_{3}\right) \mathrm{NO}\right]^{\mathrm{e}}$ & 1.99 & n.o & 1.87 & n.o. & n.o. & n.o. & [38] \\
\hline$[\operatorname{Ru}(\text { HEDTA })(N O)]^{-f}$ & 2.015 & 1.985 & 1.872 & 21.8 & 27.8 & 15.2 & [76] \\
\hline trans- $\left[\mathrm{Ru}\left(\mathrm{NH}_{3}\right)_{4}(4-\mathrm{pic}) \mathrm{NO}\right]^{2+g}$ & 2.038 & 2.003 & 1.885 & n.o & n.o & n.o & [63] \\
\hline
\end{tabular}

* The nitrosyl complexes were obtained by chemical or electrochemical reduction.

\# Cyclam =1,4,8,11-tetraazacyclotetradecane; depe=1,2-Bis(diethylphosphino)ethane; 4-pic=4-picoline or methylpyridine

a Reduced by dithionite at $\mathrm{pH} 8.0$, EPR measurements at $77 \mathrm{~K}$.

b Reduced by electrolysis in $\mathrm{CH}_{3} \mathrm{CN} / 0.1 \mathrm{M} \mathrm{Bu}_{4} \mathrm{NPF}_{6}$, EPR measurements at $3.5 \mathrm{~K}$.

c Reduced by $\mathrm{Eu}^{2+}$ in ethylene glycol/water (1:0.3), EPR measurements at $77 \mathrm{~K}$.

d Not specified experimental conditions.

e Reduced by cysteine in phosphate buffer pH 7.0, EPR measurements in ethylene glycol/water (1:1) at $77 \mathrm{~K}$.

${ }^{f}$ Reduced by $\mathrm{Eu}^{2+}$ in ethylene glycol/water (1:0.4), EPR measurements at $77 \mathrm{~K}$.

g Reduced by glutathione at pH 7.5 (TRIS buffer), EPR measurements in ethylene glycol/water (1:1) at $77 \mathrm{~K}$.

been detected and quantified by several electrochemical, spectroscopic, and chemiluminescence methods [78,79]. Despite recent publications describing the development and application of a direct method for the detection of $\mathrm{HNO}$ (using a modified gold electrode in amperometric experiments) [80-82], this molecule has been indirectly detected in most studies due to its high reactivity $[27,83]$. As noted above, some products of the reaction between nitrosothiol and thiols were detected and described in the literature [61] as indirect evidence of the formation of HNO. For example, several research groups have characterized nitrogen species, such as $\mathrm{N}_{2} \mathrm{O}, \mathrm{NH}_{2} \mathrm{OH}, \mathrm{NH}_{3}$ and sulfonamides $\left(\mathrm{RS}(\mathrm{O}) \mathrm{NH}_{2}\right.$ ), in the reaction between thiols and HNO donors [61,84-87]. HNO donors, such as Angeli's salt, are largely applied for the modification of cysteine residues in proteins, and products such as sulfinamide have been identified [86]. The suggested pathways for these reactions were simplified as illustrated in Scheme $5[61,84,86]$.

Most of the ruthenium nitrosyl complexes of the type $\left[(\mathrm{L})_{5} \mathrm{Ru}(\mathrm{NO})\right]^{n}$ ( $\mathrm{L}=$ polypyridines, pyrazine, $\mathrm{NH}_{3}$ and EDTA) have been described as HNO donors in reactions with thiols [37]. In this regard, ${ }^{15} \mathrm{~N}$ NMR investigations of the reaction of glutathione (GSH) with the labeled trans- $\left[\mathrm{Ru}\left(\mathrm{NH}_{3}\right)_{4}(4-\mathrm{pic})\left({ }^{15} \mathrm{NO}\right)\right]^{3+}$ and trans$\left[\mathrm{Ru}\left(\mathrm{NH}_{3}\right)_{4} \mathrm{P}(\mathrm{OEt})_{3}\left({ }^{15} \mathrm{NO}\right)\right]^{3+}$ ruthenium complexes in aqueous solution ( $\mathrm{pH} 7.5$ ) indicated ${ }^{15} \mathrm{NH}_{3},{ }^{15} \mathrm{NH}_{2} \mathrm{OH}$, and $\mathrm{GS}(\mathrm{O}){ }^{15} \mathrm{NH}_{2}$ as products [63]. These products were likely formed in a similar manner as suggested for other HNO donors (Scheme 5).

The pathways in Schemes 4 and 5 summarize a set of plausible reactions that can start with the simple nucleophilic addition of a thiolate ion $\left(\mathrm{RS}^{-}\right)$on the nitrosonium ligand of ruthenium complexes. However, the kinetics and products generated in this nucleophilic addition step are dependent on the electronic features of the $\left[\mathrm{RuNO}^{+}\right]$moiety and thus on thermodynamic parameters, such as the redox potential of the $\mathrm{Ru}^{\mathrm{II}} \mathrm{NO}^{+} / \mathrm{Ru}^{\mathrm{II}} \mathrm{NO} \mathrm{O}^{\bullet}$ couple. In this sense, important information and generalizations regarding the formation, stability and chemical features of the products formed from the reaction between ruthenium nitrosyl complexes and nucleophiles can be obtained by considering the kinetic $\left(k_{\mathrm{B}}\right)$ and thermodynamic $\left(E_{\mathrm{NO}+/ \mathrm{NO}}{ }^{\circ}\right)$ aspects, as will be discussed in the next section.

\subsection{Some kinetic and electrochemical aspects of thiol and hydroxide addition in ruthenium nitrosyl complexes}

A relationship between the energy of the stretching frequency of the NO group $\left(v_{\mathrm{NO}}\right)$ and both the redox potential of the $[\mathrm{RuNO}]^{n+} /[\mathrm{RuNO}]^{(n-1)+}$ couple and the corresponding rate of nucleophilic attack on the nitrosonium $\left(\mathrm{NO}^{+}\right)$ligand by hydroxyl and thiols has been experimentally observed [37,39]. This has been interpreted as a function of the population of the $\pi^{*}$ orbital of nitric oxide as a consequence of the $\mathrm{d}_{\pi}-\mathrm{p}_{\pi}$ backbonding interactions in the [Ru-NO] moiety. Stronger Ru-NO backbonding will lead to a smaller nucleophilic susceptibility of the nitrosonium ligand $[39,88]$. Furthermore, these backdonation effects are highly sensitive to the composition of the coordination sphere and to the acceptor abilities of the other ligands, as demonstrated in systems such as $\left[(\mathrm{L})_{5}\right.$ RuNO ${ }^{n}$, where $\mathrm{L}=$ ammines, polypyridines, and cyanides $[39,88]$.

The influence of trans ligands on the rate of nucleophilic addition of $\mathrm{RS}^{-}$and $\mathrm{OH}^{-}$species on the $\left[\mathrm{RuNO}^{+}\right]$moiety can be determined using the ruthenium tetraammine trans- $\left[\mathrm{Ru}^{\mathrm{II}}\left(\mathrm{NH}_{3}\right)_{4}(\mathrm{~L})\left(\mathrm{NO}^{+}\right)\right]^{n+}$ as a model $[37,69]$. The synthetic routes for these ruthenium ammines are well known $[33,35,39]$, and those compounds are more versatile than the nitroprusside ion for tailoring new nitrosyl complexes. Based on these facts, the ruthenium ammines were chosen for the development of an experimental approach to investigate their reactions with nucleophiles, such as thiols and hydroxide, with respect to the composition of the coordination sphere. In the tetraammine complexes trans- $\left[\mathrm{Ru}^{\mathrm{II}}\left(\mathrm{NH}_{3}\right)_{4}(\mathrm{~L})\left(\mathrm{NO}^{+}\right)\right]^{n+}$, the equatorial $\mathrm{NH}_{3}$ ligands are considered substantially inert regarding substitution reactions $[33,35,39,48,89]$. This allows for a focus on the reactivity of the complex along the $\mathrm{L}-\mathrm{Ru}-\mathrm{NO}$ axis, which is highly sensitive to the nature of the trans ligand L $[33,35,39]$. Although this relative inertness of the $\mathrm{NH}_{3}$ ligands is not observed in the reaction between $\left[\mathrm{Ru}\left(\mathrm{NH}_{3}\right)_{5} \mathrm{NO}^{3+}\right.$ and $\mathrm{OH}^{-}$, in which a mixture of the $\left[\mathrm{Ru}\left(\mathrm{NH}_{3}\right)_{5} \mathrm{NO}_{2}\right]^{+}$and $\left[\mathrm{Ru}\left(\mathrm{NH}_{3}\right)_{4}\left(\mathrm{NH}_{2}\right) \mathrm{NO}\right]^{2+}$ species are formed [90], it is still observed in many other cases $[39,88]$.

Table 3 displays the rates $(k)$ of the reaction of nucleophilic addition of $\mathrm{OH}^{-}$or $\mathrm{RS}^{-}$, as well as the $v_{\mathrm{NO}}$ and $E_{\mathrm{NO}+/ \mathrm{NO}}{ }^{\bullet}$ for the trans- $\left[\mathrm{Ru}\left(\mathrm{NH}_{3}\right)_{4} \mathrm{~L}(\mathrm{NO})\right]^{3+}\left(\mathrm{L}=\mathrm{P}(\mathrm{OEt})_{3}\right.$, pyrazine $(\mathrm{pz})$, pyridine (py), nicotinamide (nic), 4-chloropyridine (4-Clpy), 4-picoline (4pic), $l$-histidine (L-hist)) complexes. According to the literature, the data in Table 3 for ruthenium tetraammines suggest that a higher $\pi$-withdrawing ability of the trans ligand $\mathrm{L}$ will lead to a more positive redox potential of the $[\mathrm{RuNO}]^{n+} /[\mathrm{RuNO}]^{(n-1)+}$ couple and a higher $v_{\mathrm{NO}}$ energy [39]. In the case of trans-[ $\left.\mathrm{Ru}\left(\mathrm{NH}_{3}\right)_{4} \mathrm{~L}(\mathrm{NO})\right]^{3+}$, the complexes with the more positive redox potential for the $[\mathrm{RuNO}]^{n+} /[\mathrm{RuNO}]^{(n-1)+}$ couple and higher energy for $v_{\mathrm{NO}}$ were also found to exhibit higher rate constants $\left(k_{\mathrm{OH}}, k_{1 \mathrm{RS}}-, k_{2 \mathrm{RS} 2}-\right)$ for nucleophilic attack (Table 3 ). In fact, when the redox potential of trans- $\left[\mathrm{Ru}\left(\mathrm{NH}_{3}\right)_{4}(\mathrm{~L})(\mathrm{NO})\right]^{3+/ 2+}\left(E_{\mathrm{NO}+/ \mathrm{NO}}{ }^{\bullet}\right)$ is plotted against the 
Table 3

Rate constants $\left(k\right.$, at $\left.25^{\circ} \mathrm{C}\right)$ for the nucleophilic addition, $v_{\mathrm{NO}}, E_{\mathrm{NO}+/ \mathrm{NO}}{ }^{\bullet}$, and electrochemical Lever's parameter $\left(\Sigma \mathrm{E}_{\mathrm{L}}\right)$ values of ligand L for several nitrosyl complexes.

\begin{tabular}{|c|c|c|c|c|c|c|c|c|}
\hline Complex & Nucleophile (B) & $k_{1(\mathrm{~B})}\left(\mathrm{M}^{-1} \mathrm{~s}^{-1}\right)^{\#}$ & $k_{2(\mathrm{~B})}\left(\mathrm{M}^{-1} \mathrm{~s}^{-1}\right)^{\# \#}$ & $k_{1\left(\mathrm{RS}^{-}\right)}\left(\mathrm{M}^{-1} \mathrm{~s}^{-1}\right) *$ & $k_{2\left(\mathrm{RS}^{-}\right)}\left(\mathrm{M}^{-1} \mathrm{~s}^{-1}\right) *$ & $E_{\mathrm{NO}+/ \mathrm{NO}} \cdot(\mathrm{V} v s \mathrm{NHE})$ & $v_{\mathrm{NO}}\left(\mathrm{cm}^{-1}\right)$ & $\Sigma \mathrm{E}_{\mathrm{L}}$ \\
\hline$\left[\mathrm{Ru}(\mathrm{NO})(\mathrm{CN})_{5}\right]^{2-}$ & $\mathrm{OH}^{-}$ & $0.95[12]$ & - & - & - & $-0.153[88]$ & $1926[92]$ & - \\
\hline$\left[\mathrm{Os}(\mathrm{NO})(\mathrm{CN})_{5}\right]^{2-}$ & $\mathrm{OH}^{-}$ & $1.37 \times 10^{-4}[92]$ & - & - & - & $-0.483[88]$ & $1897[92]$ & - \\
\hline \multirow[t]{2}{*}[\mathrm{Ru}(\mathrm{NO})(\mathrm{EDTA})]{$^{-}$} & $\mathrm{OH}^{-}$ & $4.35[76]$ & - & - & - & $-0.113[76]$ & $1890[76]$ & - \\
\hline & Cysteine & - & - & $4.9 \times 10^{4 a}[12]$ & $\sim 50^{\mathrm{a}}[12]$ & & & - \\
\hline $\begin{array}{l}\text { trans- } \\
{\left[\mathrm{Ru}\left(\mathrm{NH}_{3}\right)_{4} \mathrm{P}(\mathrm{OEt})_{3}(\mathrm{NO})\right]^{3+}}\end{array}$ & Cysteine & $3.5 \times 10^{3 \mathrm{~b}}[69]$ & $3.6^{\mathrm{b}}[69]$ & $1.4 \times 10^{8}[69]$ & $1.6 \times 10^{4}[69]$ & $0.132[39]$ & 1909 [39] & $0.68[39]$ \\
\hline \multirow{2}{*}{$\begin{array}{l}{\left[\mathrm{Ru}\left(\mathrm{NH}_{3}\right)_{4} \mathrm{P}(\mathrm{OEt})_{3}(\mathrm{NO})\right]^{3+}} \\
\text { trans- } \\
{\left[\mathrm{Ru}^{3+}\left(\mathrm{NH}_{3}\right)_{4}(\mathrm{pz})(\mathrm{NO})\right]^{3+}}\end{array}$} & $\mathrm{OH}^{-}$ & $1.77 \times 10^{2}[88]$ & - & - & - & $0.112[39]$ & 1942 [39] & $0.61[39]$ \\
\hline & Cysteine & $1.6 \times 10^{5 c}[12]$ & $60^{c}[12]$ & $3.2 \times 10^{6}[12]$ & $1.2 \times 10^{3}[12]$ & & & \\
\hline \multirow{2}{*}{$\begin{array}{l}\text { trans- } \\
\left.\left[\mathrm{Ru}^{-} \mathrm{NH}_{3}\right)_{4}(\mathrm{py})(\mathrm{NO})\right]^{3+}\end{array}$} & $\mathrm{OH}^{-}$ & $14.5[88]$ & - & - & - & $0.012[39]$ & 1931 [39] & $0.53[39]$ \\
\hline & Cysteine & $3.2 \times 10^{3 \mathrm{~d}}[93]$ & $31^{\mathrm{d}}[93]$ & $2.8 \times 10^{4}[93]$ & $2.7 \times 10^{2}[93]$ & & & - \\
\hline \multirow{2}{*}{$\begin{array}{l}\text { trans- }\left[\mathrm{Ru}\left(\mathrm{NH}_{3}\right)_{4}(4-\right. \\
\text { pic)(NO) }]^{3+}\end{array}$} & $\mathrm{OH}^{-}$ & $9.54[88]$ & - & - & - & $-0.008[39]$ & 1934 [39] & $0.51[39]$ \\
\hline & Cysteine & $2.5 \times 10^{3 \mathrm{~d}}[93]$ & $13.2^{\mathrm{d}}[93]$ & $2.2 \times 10^{4}[93]$ & $4.9 \times 10^{1}[93]$ & & & \\
\hline $\begin{array}{l}\text { trans- } \\
{\left[\mathrm{Ru}\left(\mathrm{NH}_{3}\right)_{4}(\mathrm{nic})(\mathrm{NO})\right]^{3+}}\end{array}$ & $\mathrm{OH}^{-}$ & $33[88]$ & - & - & - & $0.072[39]$ & 1940 [39] & $0.56[39]$ \\
\hline $\begin{array}{l}\text { trans }-\left[\mathrm{Ru}\left(\mathrm{NH}_{3}\right)_{4}(\mathrm{~L}-\right. \\
\text { hist })(\mathrm{NO})]^{3+}\end{array}$ & $\mathrm{OH}^{-}$ & $0.76[88]$ & - & - & - & $-0.108[39]$ & 1921 [39] & $0.42[39]$ \\
\hline $\begin{array}{l}\text { trans }-\left[\mathrm{Ru}\left(\mathrm{NH}_{3}\right)_{4}(4-\right. \\
\text { Clpy)(NO) }]^{3+}\end{array}$ & $\mathrm{OH}^{-}$ & $26[88]$ & - & - & - & $0.012[39]$ & $1928[39]$ & $0.54[39]$ \\
\hline \multirow[t]{2}{*}{ cis- $\left[\mathrm{Ru}(\mathrm{NO})(\mathrm{bpy})_{2} \mathrm{Cl}\right]^{2+}$} & $\mathrm{OH}^{-}$ & $8.5 \times 10^{3}[88]$ & - & - & - & $0.247[88]$ & $1933[88]$ & - \\
\hline & Cysteine & $9.6 \times 10^{3 \mathrm{e}}[37]$ & $3.2^{\mathrm{e}}[37]$ & $1.5 \times 10^{8}[37]$ & $4.0 \times 10^{4}[37]$ & & & - \\
\hline \multirow[t]{2}{*}{$\begin{array}{l}\text { cis- } \\
{\left[\mathrm{Ru}(\mathrm{NO})(\mathrm{bpy})_{2} \mathrm{NO}_{2}\right]^{2+}}\end{array}$} & $\mathrm{OH}^{-}$ & $5.06 \times 10^{4}[88]$ & - & - & - & $0.377[88]$ & $1942[88]$ & - \\
\hline & Cysteine & $1.36 \times 10^{4 \mathrm{e}}[12]$ & $11.6^{\mathrm{e}}[12]$ & $2.7 \times 10^{8}[12]$ & $2.3 \times 10^{5}[12]$ & & & - \\
\hline \multirow{2}{*}{$\begin{array}{l}\text { cis- } \\
{\left[\mathrm{Ru}(\mathrm{NO})(\mathrm{bpy})_{2}(\mathrm{AcN})\right]^{2+}}\end{array}$} & $\mathrm{OH}^{-}$ & $5.6 \times 10^{6}[88]$ & - & - & - & $0.547[88]$ & $1960[88]$ & - \\
\hline & Cysteine & $2.89 \times 10^{4 \mathrm{e}}[12]$ & $18^{\mathrm{e}}[12]$ & $5.8 \times 10^{8}[12]$ & $3.6 \times 10^{5}[12]$ & & & - \\
\hline \multirow{2}{*}{$\begin{array}{l}\text { cis- } \\
{\left[\mathrm{Ru}(\mathrm{NO})(\mathrm{bpy})_{2}\left(\mathrm{SO}_{3}\right)\right]^{+}}\end{array}$} & Cysteine & - & $154^{\mathrm{C}}[38]$ & - & $2.2 \times 10^{9}[38]$ & $0.057[38]$ & $1911[38]$ & - \\
\hline & Glutathione & - & $11.8^{\mathrm{c}}[38]$ & - & $6.7 \times 10^{8}[38]$ & & & - \\
\hline \multirow{2}{*}{$\begin{array}{l}\text { cis- } \\
{\left[\mathrm{Ru}(\mathrm{NO})(\mathrm{bpy})_{2}(\mathrm{ImN})\right]^{2+}}\end{array}$} & Cysteine & - & $0.84^{\mathrm{f}}[38]$ & - & $1.3 \times 10^{9}[38]$ & $0.397[38]$ & $1944[38]$ & - \\
\hline & Glutathione & - & $0.32^{\mathrm{f}}[38]$ & - & $2.5 \times 10^{8}[38]$ & & & - \\
\hline \multirow[t]{2}{*}[\mathrm{Ru}(\mathrm{NO})(\mathrm{bpy})(\mathrm{tpy})]{$^{3+}$} & $\mathrm{OH}^{-}$ & $3.17 \times 10^{5}[88]$ & - & - & - & $0.447[88]$ & $1946[88]$ & - \\
\hline & Cysteine & $2.67 \times 10^{4 \mathrm{e}}[12]$ & $35^{\mathrm{e}}[12]$ & $5.3 \times 10^{8}[12]$ & $7.0 \times 10^{5}[12]$ & & & - \\
\hline \multirow[t]{2}{*}[\mathrm{Ru}(\mathrm{NO})(\mathrm{bpz})(\mathrm{tpy})]{$^{3+}$} & $\mathrm{OH}^{-}$ & $7.6 \times 10^{6}[37]$ & - & - & - & $0.657[37]$ & - & - \\
\hline & Cysteine & $3.56 \times 10^{4 e}[12]$ & $179^{\mathrm{e}}[12]$ & $7.1 \times 10^{8}[12]$ & $3.6 \times 10^{6}[12]$ & & - & - \\
\hline
\end{tabular}

\# $k_{1(\mathrm{~B})}$ is the first addition of the nucleophiles $\mathrm{B}=\mathrm{OH}^{-}$or thiol total $\left([\mathrm{RSH}]_{\text {total }}=[\mathrm{RSH}]+\left[\mathrm{RS}^{-}\right]\right)$to metal nitrosyls.

\#\# $k_{2(\mathrm{~B})}$ is the second addition of thiols considering the thiol total ([RSH] $]_{\text {total }}$ ).

${ }^{*} k_{1\left(\mathrm{RS}^{-}\right)}$and $k_{2\left(\mathrm{RS}^{-}\right)}$are respectively the first and second additions of the thiols to metal nitrosyls considering only the deprotonated species ( $\mathrm{RS}^{-}$).

a $\mathrm{pH} 9.9(\mu=1 \mathrm{M})$.

b $\mathrm{pH} 3.5(\mu=0.1 \mathrm{M})$.

c $\mathrm{pH} 7.0(\mu=0.1 \mathrm{M})$.

d $\mathrm{pH} 7.4(\mu=0.2 \mathrm{M})$.

e $\mathrm{pH} 4.0(\mu=1 \mathrm{M})$.

${ }^{\mathrm{f}} \mathrm{pH} 4.0(\mu=0.1 \mathrm{M})$.

values of $k_{\mathrm{OH}^{-}}-$or $k_{1 \mathrm{RS}}-$ and $k_{2 \mathrm{RS}}-$, a linear free energy relationship (LFER) is observed (Fig. 2). The relatively similar slopes observed in Fig. 2 reasonably suggest an analogous mechanism for the nucleophilic addition of $\mathrm{OH}^{-}$and $\mathrm{RS}^{-}$to ruthenium nitrosyl complexes $[12,88,91]$.

The relationship between the electronic properties of the trans ligands (L) in trans-[ $\left.\mathrm{Ru}\left(\mathrm{NH}_{3}\right)_{4}(\mathrm{~L})(\mathrm{NO})\right]^{3+}$ and the rate constants for nucleophilic addition can be better envisaged when plotting $k_{\mathrm{RS}}-$ or $k_{\mathrm{OH}}$ - as a function of $\Sigma E_{\mathrm{L}}$ (the sum of $E_{\mathrm{L}}$, the ligand electrochemical parameter - Lever's parameter) [94] (Fig. 3). This parameter is a useful model for describing the redox potential/structure relationships in metal complexes [94]. Thus, because similar slopes are observed for the curves in Fig. 3 and considering the LFER for the trans- $\left[\mathrm{Ru}\left(\mathrm{NH}_{3}\right)_{4}(\mathrm{~L})(\mathrm{NO})\right]^{3+}$ system (Fig. 2), the mechanism of the addition of $\mathrm{RS}^{-}$likely follows a similar pathway to the one for the reaction with $\mathrm{OH}^{-}[37,88]$. An increase in the $E_{\mathrm{L}}$ reflects an increase in the nitrosonium character [39] as a function of $\mathrm{L}$ in the order L-hist $<4$-pic $\sim \mathrm{py}<$ nic $\sim \mathrm{pz}<\mathrm{P}(\mathrm{OEt})_{3}$ in the

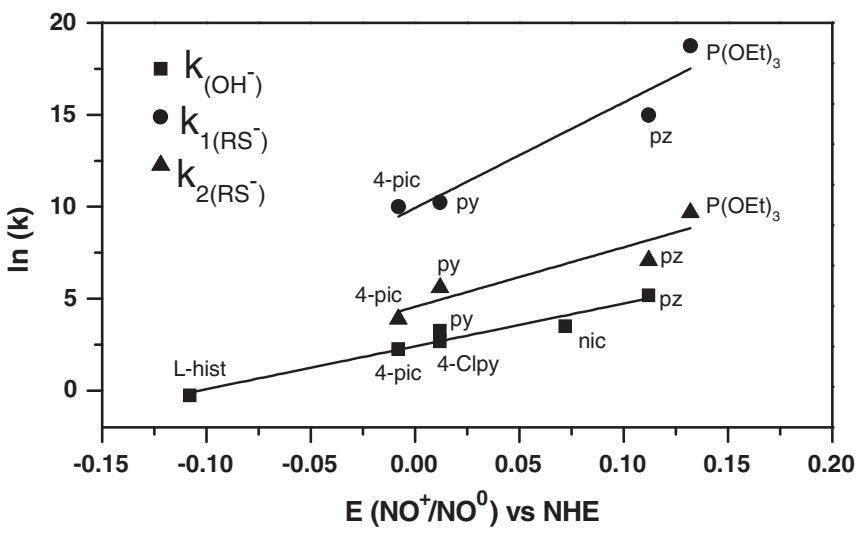

Fig. 2. Linear free energy relationships (LFERs), based on the redox potential $\left(E_{\mathrm{NO}+/ \mathrm{NO}}{ }^{\bullet}\right)$, for the reactions of a series of trans-[Ru( $\left.\left.\mathrm{NH}_{3}\right)_{4}(\mathrm{~L})(\mathrm{NO})\right]^{3+}$ complexes with $\mathrm{RS}^{-}$and $\mathrm{OH}^{-}$(data from Table 3). The abbreviations in the graphic refer to ligand $\mathrm{L}$. 
Table 4

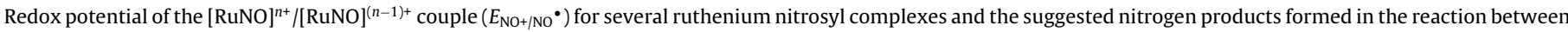
nitrosyl complexes and thiols.

\begin{tabular}{|c|c|c|c|c|}
\hline Complex & $E_{\mathrm{NO}+/ \mathrm{NO}^{\circ}}(\mathrm{V}$ vs $\mathrm{NHE})$ & Primary products & Secondary products & Ref \\
\hline trans- $\left[\mathrm{Ru}\left(\mathrm{NH}_{3}\right)_{4}(4-\mathrm{pic})(\mathrm{NO})\right]^{3+}$ & -0.008 & $\mathrm{HNO} / \mathrm{NO}^{\mathrm{a}}$ & $\mathrm{NH}_{3}$ & [63] \\
\hline cis- $\left[\mathrm{Ru}(\mathrm{NO})(\mathrm{bpy})_{2}\left(\mathrm{SO}_{3}\right)\right]^{2+}$ & 0.057 & $\mathrm{NO}^{\mathrm{b}}$ & - & [38] \\
\hline trans- $\left[\mathrm{Ru}\left(\mathrm{NH}_{3}\right)_{4} \mathrm{P}(\mathrm{OEt})_{3}(\mathrm{NO})\right]^{3+}$ & 0.132 & $\mathrm{HNO} / \mathrm{NO}^{\mathrm{c}}$ & $\mathrm{NH}_{3} / \mathrm{NH}_{2} \mathrm{OH} / \mathrm{N}_{2} \mathrm{O} / \mathrm{GS}(\mathrm{O}) \mathrm{NH}_{2}$ & {$[63,69]$} \\
\hline cis- $\left[\mathrm{Ru}(\mathrm{NO})(\mathrm{bpy})_{2} \mathrm{Cl}\right]^{2+}$ & 0.247 & $\mathrm{HNO}^{\mathrm{d}}$ & $\mathrm{N}_{2} \mathrm{O}$ & [37] \\
\hline cis- $\left[\mathrm{Ru}(\mathrm{NO})(\mathrm{bpy})_{2}\left(\mathrm{NO}_{2}\right)\right]^{2+}$ & 0.377 & $\mathrm{HNO}^{\mathrm{d}}$ & $\mathrm{N}_{2} \mathrm{O}$ & [37] \\
\hline cis-[Ru(NO)(bpy $\left.)_{2}(\mathrm{imN})\right]^{2+}$ & 0.397 & $\mathrm{NO}^{\mathrm{e}}$ & - & [38] \\
\hline$[\mathrm{Ru}(\mathrm{NO})(\mathrm{bpy})(\mathrm{tpy})]^{3+}$ & 0.447 & $\mathrm{HNO}^{\mathrm{d}}$ & $\mathrm{N}_{2} \mathrm{O}$ & [37] \\
\hline cis- $\left[\mathrm{Ru}(\mathrm{NO})(\mathrm{AcN})(\mathrm{bpy})_{2}\right]^{2+}$ & 0.547 & $\mathrm{HNO}^{\mathrm{d}}$ & $\mathrm{N}_{2} \mathrm{O}$ & [37] \\
\hline
\end{tabular}

* NO and HNO are proposed to be generate on the coordinated sphere and then rapidly released.

\# Products from the HNO reactions after its release from the coordinated sphere.

a Detection of $\mathrm{NO}$ and $\mathrm{NH}_{3}$ at $\mathrm{pH} 7.5$ (reaction with cysteine and glutathione).

b Detection of NO at pH 7.0 (reaction with cysteine and glutathione).

c Detection of NO, $\mathrm{N}_{2} \mathrm{O}, \mathrm{NH}_{3}$ and other nitrogen based species at $\mathrm{pH}$ range 3.0-7.5 (reaction with cysteine and glutathione).

d Detection of $\mathrm{N}_{2} \mathrm{O}$ at $\mathrm{pH} 4.0$ (reaction with cysteine).

e Detection of NO at $\mathrm{pH} 4.0$ (reaction with cysteine and glutathione).

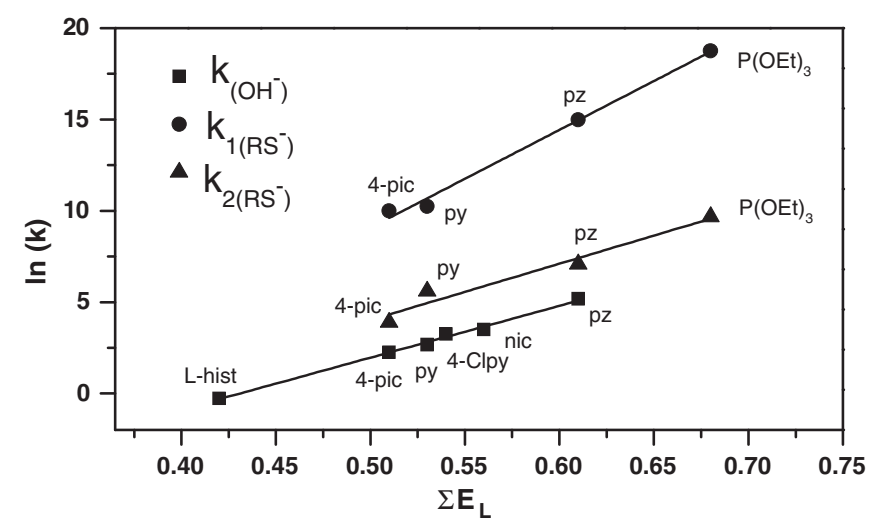

Fig. 3. Linear free energy relationships (LFERs), based on the sum of the electrochemical parameter of the ligand $\left(\Sigma E_{\mathrm{L}}\right)$, for the reactions of a series of trans- $\left[\mathrm{Ru}\left(\mathrm{NH}_{3}\right)_{4}(\mathrm{~L})(\mathrm{NO})\right]^{3+}$ complexes with $\mathrm{RS}-$ and $\mathrm{OH}-$ (data from Table 3 ). The abbreviations in the graphic refer to ligand $\mathrm{L}$.

trans- $\left[\mathrm{Ru}\left(\mathrm{NH}_{3}\right)_{4}(\mathrm{~L})(\mathrm{NO})\right]^{3+}$ system [39]. Thus, the extent of the nucleophilic attack in trans- $\left[\mathrm{Ru}\left(\mathrm{NH}_{3}\right)_{4}(\mathrm{~L})(\mathrm{NO})\right]^{3+}$ can be controlled by changing the trans ligand $\mathrm{L}$.

According to the above discussion, there are certainly similarities in the kinetic aspects of the reactions between ruthenium nitrosyls and the $\mathrm{OH}^{-}$and $\mathrm{RS}^{-}$nucleophiles $[37,88]$. However, this is not true regarding the reaction products. No oxidation/reduction process occurs in the case of $\mathrm{OH}^{-}$addition, where the final products are the nitro species $[39,88]$. However, in the reactions with $\mathrm{RS}^{-}$, a diversity of products is possible due to the redox processes involving the thiol and the intermediate products of this reaction $[10,11,34,37,38,69]$. Moreover, the excess of thiols also influences the final products formed (Scheme 4 and Table 4) [69].

According to the data in Table 4, the redox potential of the $[\mathrm{RuNO}]^{n+} /[\mathrm{RuNO}]^{(n-1)+}$ couple, when considered in isolation, is not a sufficient parameter to predict when NO and/or HNO will be produced in the reaction between nitrosyl complexes and thiols. For example, complexes having close $E_{\mathrm{NO}+/ \mathrm{NO}} \bullet$ values do not lead to the same final products (Table 4). Moreover, in the case of trans- $\left[\mathrm{Ru}\left(\mathrm{NH}_{3}\right)_{4}(4-\mathrm{pic})(\mathrm{NO})\right]^{3+}$, the complex with the less positive $E_{\mathrm{NO}+\mathrm{NO}} \cdot$ value in Table 4 is able to release both $\mathrm{NO}$ and HNO [63]. This same behavior is also observed for the trans$\left[\mathrm{Ru}\left(\mathrm{NH}_{3}\right)_{4} \mathrm{P}(\mathrm{OEt})_{3}(\mathrm{NO})\right]^{3+}$ complex [69].

Part of the explanation about the formation of NO or HNO is likely related to the stability of the adduct formed after the first nucleophilic addition (Eq. (7) and Scheme 4) on metal nitrosyls. This adduct has different chemical properties with respect to the corresponding original nitrosyl complex (Table 1). In this regard, the following step, which is either the decomposition of the first adduct or the nucleophilic addition of a second thiol (Scheme 4), will be dependent on the stability of the first adduct. This stability, which is related to the intrinsic electronic characteristics of the metal complex, is a theme to be explored with a series of nitrosyl complexes to identify the most relevant parameters that will define the reaction pathway (Scheme 4). Despite this discussion, the redox potential remains a guide to evaluate nucleophilic addition in metal nitrosyls.

\section{Thiol-responsive nitric oxide-releasing materials}

Different classes of compounds, such as S-nitrosothiols (RSNO), diazeniumdiolates (NONOates) [95,96], metal nitrosyls [39], and organic nitrites/nitrates, have been synthesized and investigated as NO-releasing compounds. Many NO-releasing materials (NORMs) have also been developed by associating these NO donors with different materials, such as silica, micelles, dendrimers, polymers and hydrogels [47,96-99]. Most of these materials can be molded and/or modified, resulting in different shapes, such as fibers, films, and nanoparticles, which can be used as platforms for nitric oxide delivery. The main advantage of NORMs is the possibility to tune the structural properties of the matrices (e.g., surface functionalities, size) and the parameters of NO release (e.g., kinetics, payload, and control of NO release) $[47,96,98-106]$.

One of the main challenges associated with NO therapy is the release of the desired amounts of NO in a controlled manner. Many of the NORMs are produced using compounds that spontaneously release NO in physiological media (e.g., diazeniumdiolates $[95,99])$. Although these materials work well in various situations, NO release is spontaneously initiated in physiological media, and controlling that release is limited to chemical modifications in the nature of the NO-donor moiety or in the material. One of the strategies employed to overcome the intrinsic shortcomings of such NO donors is the use of light to induce NO donation. Light is a noninvasive trigger that can be used for the spatiotemporal control of NO delivery, with the advantage of not strongly affecting physiological parameters, such as temperature, ionic strength, and $\mathrm{pH}$ [103]. In this regard, the literature describes different devices capable of NO release induced by light $[47,96,97,99,103-105,107-115]$.

Despite the advantages of using light to induce NO donation, this trigger (light) is not practical in some situations, such as ischemia/reperfusion injury [116]. Moreover, during reperfusion, large concentrations of superoxide are produced, which limits the use of spontaneous NO donors, such as $N$-diazeniumdiolates [116]. One of the alternatives for such situations is NO donation triggered by endogenous compounds. For example, $S$-nitrosothiols are able 


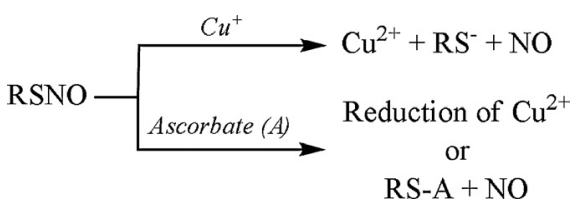

Scheme 6. Decomposition of S-nitrosothiol [96].

to release NO by copper-mediated decomposition [97,117] and by reaction with ascorbate $[97,118]$ according to Scheme 6 (NO release by $S$-nitrosothiols is also triggered by heat and light $[96,98,119])$.

Another example is the decomposition of $S$-nitrosothiols (RSNO) in the presence of glutathione (GSH) or other thiols (RSH), resulting in NO and HNO release $[61,116]$. In this regard, Johnson et al. [116] synthesized polyamidoamine (PAMAM) dendrimers surfacefunctionalized with $S$-nitroso- $N$-acetylpenicillamine (SNAP) as a NO donor, in which the release of NO was initiated by the addition of glutathione (GSH) [116]. The exposition of these S-nitrosothiolmodified dendrimers (G4-SNAP) to GSH [116] increased the total amount and rate of NO release compared with spontaneous NO delivery at physiological conditions (phosphate buffered saline, $\mathrm{pH}$ 7.4 at $37^{\circ} \mathrm{C}$, without GSH). The greatest rate and total amount of NO release was verified for a GSH-to-SNAP ratio of 25:1 for $0.5 \mathrm{mM}$ of GSH [116]. Moreover, increasing the GSH concentrations caused a dose-dependent decrease in the total amount of released NO. This was attributed to the scavenging of NO by GSH at more elevated concentrations of the thiol [116]. Despite this drawback, therapy using the thiol dendrimer G4-SNAP in association with GSH minimized ischemia/reperfusion in an ex vivo heart model with a significant reduction of the optimal therapeutic dose (effective) compared with free SNAP (not attached to the dendrimer) [116].

Another example of biological stimuli-responsive NORM is a biodegradable starch-based film impregnated with the nitrosyl complex trans- $\left[\mathrm{Ru}\left(\mathrm{NH}_{3}\right)_{4}(\mathrm{isn}) \mathrm{NO}\right]\left(\mathrm{BF}_{4}\right)_{3}$ (this complex is abbreviated as RuNOisn; isn =isonicotinamide) $[114,120]$. This material (CS-RuNOisn) was able to release NO when triggered by light as well as by reaction with cysteine. In principle, this effect can also be caused by other biological species or other suitable reductants $[48,121]$. In these systems, NO release was only initiated by the addition of cysteine, and the time to reach maximum NO flux was similar for both the immobilized and non-immobilized RuNOisn [114]. A similar behavior was also observed for the other NO-release parameters [78] for the cysteine-initiated NO release, e.g., the total amount of released NO, duration, half-life, and maximum flux [114]. Starch-based films released physiologically relevant NO concentrations for more than $7 \mathrm{~h}$, with an average NO flux of $\sim 1.9 \mathrm{pmol}$ $\mathrm{s}^{-1} \mathrm{~cm}^{-2}$, which was similar to that produced by endothelial cells [122] ( $1.67 \mathrm{pmol} \mathrm{s}^{-1} \mathrm{~cm}^{-2}$ ). The total amount and half-life $\left(t_{1 / 2}\right)$ of NO release verified for $1 \mathrm{~cm}^{2}$ of CS-RuNOisn were $49 \pm 5 \mathrm{nmol}$ of NO and $t_{1 / 2}=1.65 \pm 0.22 \mathrm{~h}$, respectively, which were close to the values obtained for RuNOisn in solution [114]. Such results are in agreement with those of other ruthenium nitrosyl complexes, in which the chemical properties in solution were maintained after immobilization in different matrices [46,115]. Despite the total amount of NO released from the ruthenium nitrosyl (immobilized or in solution) has physiological relevance, this amount was only $2.5-3.5 \%$ of the total RuNOisn content used in the assays. This low level of NO released was attributed to the formation of other products, and among them, likely HNO [114].

Other advantages of starch-based films are their mechanical properties, their in vivo degradation, and the ability to mold them as needed $[114,120]$. Such characteristics enable these films to be used as coating materials for NO release. Additionally, due to the mild conditions used for the preparation of the starch-based films, this platform can also be used for the transport and delivery of other drugs [114].
Silva et al. [123], employing a similar strategy, functionalized mesoporous silica spheres with isonicotinic acid to coordinate the cis- $\left[\mathrm{Ru}(\mathrm{bpy})_{2}(\mathrm{~L}) \mathrm{NO}^{3+}{ }^{3}\right.$ bpy $=2,2^{\prime}$-bipyridine $)$ and $\left[\mathrm{Fe}(\mathrm{CN})_{4}(\mathrm{~L}) \mathrm{NO}\right]^{-}$ ( $\mathrm{L}=$ isonicotinic acid immobilized on silica) complexes on the surface of the silica. NO release was observed with these materials upon light irradiation ( $350 \mathrm{~nm}$ ) as well as via a reaction with cysteine (phosphate buffer solution, pH 7.0) [123]. In these systems, sluggish NO release kinetics were observed for the iron complex compared with the ruthenium system upon both photolysis and reaction with cysteine [123]. The authors suggested that this behavior was likely due to the labilizing effect of the chelating ligand bpy, which facilitates NO release from the ruthenium nitrosyl complex [123].

Others strategies have also been developed for biological responsive NO release, in which materials have been impregnated with copper complexes and nanoparticles for the catalytic generation of NO by contact with solutions containing S-nitrosothiols (simulating physiological conditions) as well as with blood. Readers are directed to the following selected references for a more in-depth discussion [97,124-129]. The main advantage of such materials is the unlimited source of nitric oxide, which can be generated at the material/blood interface, compared to materials containing a finite reservoir of NO donors.

In conclusion, despite the relative scarcity of available literature on thiol-responsive nitric oxide-releasing materials, the use of thiols or other biological triggers for NO release represents a novel strategy with clinical relevance, mainly for ischemic tissue therapy [116].

\section{Concluding remarks}

In the last few years, advances in kinetic studies and product analysis of the reaction between metal nitrosyl complexes and several nucleophiles have provided important chemical and biological insights with respect to NO and HNO molecules. The recent literature led to significant advancements regarding the development of NO-donor platforms based on metal complexes with recognized physiological and pharmacological effects. Since the first studies on the nitroprusside ion complex, the number of studied compounds having clinical uses has increased considerably. The current studies involving the reaction products of the nitroprusside ion and hydrogen sulfide, a secular theme, provide a new and scientifically important framework.

The new nitrosyl metallic systems are now studied to design compounds with well-defined chemical and electronic structures. Such investigations are mainly performed by modulating the thermodynamic and kinetic properties of the nitrosonium ligand, which can be governed by the coligands. Ruthenium nitrosyl complexes have been useful for exploring the nucleophilic addition of important species, such as cysteine and glutathione (RS ${ }^{-}$), which are abundant in biological media. Both NO and HNO, as well as the respective ruthenium(II) aquo complexes, are the suggested intermediate products of the reaction between $\left[(\mathrm{L})_{5} \mathrm{RuNO}\right]^{n}$ ( $\mathrm{L}=$ polypyridine, pyrazine, EDTA, $\mathrm{NH}_{3}$ ) and $\mathrm{RS}^{-}$species. However, the generation of these products occurs via the formation of the nitrosothiol complex $\left[(\mathrm{L})_{5} \mathrm{RuN}(\mathrm{O}) \mathrm{SR}\right]^{n-1}$, which can present variable electronic and stability features, based on the distribution of the additional negative charge provided by the nucleophile $\left(\mathrm{RS}^{-}\right)$in the complex. This effect is mainly due to the nitrogen and ruthenium atoms of the $[\operatorname{RuN}(\mathrm{O}) \mathrm{SR}]$ moiety but also to the $\mathrm{L}$ ligands. In these aspects, ruthenium nitrosyl ammines, trans$\left[\mathrm{Ru}\left(\mathrm{NH}_{3}\right)_{4}(\mathrm{~L})(\mathrm{NO})\right]^{n+}$, present a convenient and useful structure because the electrophilic character of the NO ligand can be modulated as a function of the $\sigma$ and $\pi$ electronic properties of $L$, without a major influence of the ammine ligands. The isolation of 
a manageable compound such as trans- $\left[\mathrm{Ru}\left(\mathrm{NH}_{3}\right)_{4}(\mathrm{~L}) \mathrm{N}(\mathrm{O}) \mathrm{SR}\right](\mathrm{X})_{\mathrm{n}}$, similar to the trans- $(\mathrm{A})_{\mathrm{n}}\left[\operatorname{Ir}(\mathrm{Cl})_{4}(\mathrm{~L}) \mathrm{N}(\mathrm{O}) \mathrm{SR}\right]$ [32], would provide a promising platform to better clarify aspects of the addition of the second thiol group on the nitrosyl moiety. Complexes such as trans- $\left[\mathrm{Ru}\left(\mathrm{NH}_{3}\right)_{4}(\mathrm{~L}) \mathrm{N}(\mathrm{O}) \mathrm{SR}\right](\mathrm{X})_{n}$, can provide relevant insight on the chemistry of nitrosothiols, transnitrosylation reactions with reduced thiols, and the transport, storage and release of $\mathrm{NO}$ and HNO in situ and in vivo. It is important to gain new perspectives on the behavior observed for these nitrosyls in biological tests and thus support the results obtained for the vasodilator properties, the trypanocidal (Trypanosoma cruzi and Leishmania major) and the anticancer activity exhibited by compounds trans- $\left[\mathrm{Ru}\left(\mathrm{NH}_{3}\right)_{4}(\mathrm{~L})(\mathrm{NO})\right]^{3+}$, which are credited to their NOand $\mathrm{HNO}$-donor properties.

The fact that the nitrosyl complexes trans- $\left[\mathrm{Ru}\left(\mathrm{NH}_{3}\right)_{4}(\mathrm{~L})(\mathrm{NO})\right]^{3+}$ exhibit the same properties when in solution or when immobilized on degradable cassava starch films and other supports is an additional incentive to the application of this system as biomedical devices [99,116,130], mainly in ischemia/reperfusion injury [116], in which thiols or reductant species can trigger NO and/or HNO release.

\section{Acknowledgements}

The authors are grateful for the financial support by the Brazilian agencies FAPESP and CNPq (Grant Nos. 2012/23651-4 and 475631/2011-0, respectively) and CAPES.

\section{References}

[1] N.V. Sidgwick, The Chemical Elements and Their Compounds, vol. 2, Oxford University Press, London, 1950.

[2] C. Boedeker, Liebigs Ann. Chem. 117 (1861) 193-195.

[3] L. Playfair, Annal. der Chem. und Pharm. 373-373 (1849) 317-340.

[4] J.H. Swinehart, Coord. Chem. Rev. 2 (1967) 385-402.

[5] G.E. Alluisetti, A.E. Almaraz, V.T. Amorebieta, F. Doctorovich, J.A. Olabe, J. Am. Chem. Soc. 126 (2004) 13432-13442.

[6] M.M. Gutierrez, J.A. Olabe, V.T. Amorebieta, Eur. J. Inorg. Chem. (2012) 4433-4438.

[7] J.A. Olabe, Dalton Trans. (2008) 3633-3648.

[8] F. Roncaroli, M. Videla, L.D. Slep, J.A. Olabe, Coord. Chem. Rev. 251 (2007) 1903-1930.

[9] F. Bottomley, W.V.F. Brooks, D.E. Paez, P.S. White, M. Mukaida, J. Chem. Soc. Dalton Trans. (1983) 2465-2472.

[10] M.R. Filipovic, M. Eberhardt, V. Prokopovic, A. Mijuskovic, Z. Orescanin-Dusic, P. Reeh, I. Ivanovic-Burmazovic, J. Med. Chem. 56 (2013) 1499-1508.

[11] S.L. Quiroga, A.E. Almaraz, V.T. Amorebieta, L.L. Perissinotti, J.A. Olabe, Chem. Eur. J. 17 (2011) 4145-4156

[12] F. Roncaroli, R. van Eldik, J.A. Olabe, Inorg. Chem. 44 (2005) 2781-2790.

[13] K. Szacilowski, A. Wanat, A. Barbieri, E. Wasielewska, M. Witko, G. Stochel, Z. Stasicka, New J. Chem. 26 (2002) 1495-1502.

[14] M.D. Johnson, R.G. Wilkins, Inorg. Chem. 23 (1984) 231-235.

[15] A.R. Butler, A.M. Calsyharrison, C. Glidewell, P.E. Sorensen, Polyhedron 7 (1988) 1197-1202.

[16] A.R. Butler, A.M. Calsyharrison, C. Glidewell, I.L. Johnson, J. Reglinski, W.E. Smith, Inorg. Chim. Acta 151 (1988) 281-286.

[17] N.E. Francoleon, S.J. Carrington, J.M. Fukuto, Arch. Biochem. Biophys. 516 (2011) 146-153.

[18] V.L. Lockamy, H. Shields, D.B. Kim-Shapiro, S.B. King, Biochim. Biophys. Acta: Gen. Subj. 1674 (2004) 260-267.

[19] F.Q. Schafer, G.R. Buettner, Free Radic. Biol. Med. 30 (2001) 1191-1212.

[20] S.B. King, Free Radic. Biol. Med. 55 (2013) 1-7.

[21] R.F. Furchgott, J.V. Zawadzki, Nature 288 (1980) 373-376.

[22] L.J. Ignarro, G.M. Buga, K.S. Wood, R.E. Byrns, G. Chaudhuri, Proc. Natl. Acad. Sci. U. S. A. 84 (1987) 9265-9269.

[23] L.J. Ignarro, R.E. Byrns, G.M. Buga, K.S. Wood, Circ. Res. 61 (1987) 866-879.

[24] S. Konstadt, J. Cardiothorac. Vasc. Anesth. 9 (1995) 625-626.

[25] E. Culotta, D.E. Koshland, Science 258 (1992) 1862-1865.

[26] D.E. Koshland, Science 258 (1992), 1861-1861.

[27] K.M. Miranda, Coord. Chem. Rev. 249 (2005) 433-455.

[28] F.T. Bonner, G.R. Stedman (Eds.), Methods in Nitric Oxide Research, John Wiley \& Sons, New York, 1996, pp. 3-18.

[29] K.M. Miranda, H.T. Nagasawa, J.P. Toscano, Curr. Top. Med. Chem. 5 (2005) 649-664.

[30] D.A. Wink, K.M. Miranda, T. Katori, D. Mancardi, D.D. Thomas, L. Ridnour, M.G. Espey, M. Feelisch, C.A. Colton, J.M. Fukuto, P. Pagliaro, D.A. Kass, N. Paolocci, Am J Physiol: Heart Circ Physiol 285 (2003) H2264-H2276.
[31] D. Kazhdan, L.L. Perissinotti, B. Watanabe, M.N. Eberlin, H.M.S. Milagre, B.G. Vaz, D.A. Estrin, F. Doctorovich, Inorg. Chim. Acta 366 (2011) 85-90.

[32] L.L. Perissinotti, G. Leitus, L. Shimon, D. Estrin, F. Doctorovich, Inorg. Chem. 47 (2008) 4723-4733.

[33] S.S. Borges, C.U. Davanzo, E.E. Castellano, Z. Schpector, J.S.C. Silva, D.W. Franco Inorg. Chem. 37 (1998) 2670-2677.

[34] M.R. Filipovic, I. Ivanovic-Burmazovic, Chem. Eur. J. 18 (2012) 13538-13540

[35] M.G. Gomes, C.U. Davanzo, S.C. Silva, L.G.F. Lopes, P.S. Santos, D.W. Franco, J Chem. Soc. Dalton Trans. (1998) 601-607.

[36] G. Metzker, E.V.Stefaneli, J.C.M. Pereira, F.D.A. Lima, S.C. da Silva, D.W. Franco, Inorg. Chim. Acta 394 (2013) 765-769.

[37] F. Roncaroli, J.A. Olabe, Inorg. Chem. 44 (2005) 4719-4727.

[38] F.O.N. Silva, M.C.L. Candido, A.K.M. Holanda, I.C.N. Diogenes, E.H.S. Sousa L.G.F. Lopes, J. Inorg. Biochem. 105 (2011) 624-629.

[39] E. Tfouni, M. Krieger, B.R. McGarvey, D.W. Franco, Coord. Chem. Rev. 236 (2003) 57-69.

[40] D.R. Truzzi, D.W. Franco, Inorg. Chim. Acta 421 (2014) 74-79.

[41] P. Rock, J.H. Swinehart, Inorg. Chem. 5 (1966) 1078-1079.

[42] J.H. Swinehart, P. Rock, Inorg. Chem. 5 (1966) 573-576.

[43] M. Whiteman, L. Li, I. Kostetski, S.H. Chu, J.L. Siau, M. Bhatia, P.K. Moore Biochem. Biophys. Res. Commun. 343 (2006) 303-310.

[44] Q.C. Yong, L.F. Hu, S. Wang, D. Huang, J.S. Bian, Cardiovasc. Res. 88 (2010) 482-491.

[45] J. Schmidt, H. Kuhr, W.L. Dorn, J. Kopf, Inorg. Nucl. Chem. Lett. 10 (1974) 55-61

[46] E. Tfouni, F.G. Doro, L.E. Figueiredo, J.C.M. Pereira, G. Metzker, D.W. Franco Curr. Med. Chem. 17 (2010) 3643-3657.

[47] E. Tfouni, F.G. Doro, A.J. Gomes, R.S. da Silva, G. Metzker, P.G.Z. Benini, D.W Franco, Coord. Chem. Rev. 254 (2010) 355-371.

[48] J.C. Toledo, H.A.S. Silva, M. Scarpellini, V. Mori, A.J. Camargo, M. Bertotti, D.W Franco, Eur. J. Inorg. Chem. (2004) 1879-1885.

[49] B.F. Barros, J.C. Toledo Jr., D.W. Franco, E. Tfouni, M.H. Krieger, Nitric Oxide 7 (2002) 50-56.

[50] J.J. Silva, A.L. Osakabe, W.R. Pavanelli, J.S. Silva, D.W. Franco, Br. J. Pharmacol 152 (2007) 112-121.

[51] J.J. Silva, W.R. Pavanelli, J.C. Pereira, J.S. Silva, D.W. Franco, Antimicrob. Agents Chemother. 53 (2009) 4414-4421.

[52] J.J.N. Silva, P.M.M. Guedes, A. Zottis, T.L. Balliano, F.O.N. Silva, L.G.F. Lopes, J Ellena, G. Oliva, A.D. Andricopulo, D.W. Franco, J.S. Silva, Br. J. Pharmacol. 160 (2010) 260-269

[53] J.C.M. Pereira, V. Carregaro, D.L. Costa, J.S. da Silva, F.Q. Cunha, D.W. Franco, Eur. J. Med. Chem. 45 (2010) 4180-4187.

[54] R.Z. Osti, F.A. Serrano, T. Paschoalin, M.H.S. Massaoka, L.R. Travassos, D.R Truzzi, E.G. Rodrigues, D.W. Franco, Aust. J. Chem. 65 (2012) 1333-1341.

[55] I. Aguiar, A. Tavares, A.C. Roveda Jr., A.C. da Silva, L.B. Marino, E.O. Lopes, F.R Pavan, L.G. Lopes, D.W. Franco, Eur. J. Pharm. Sci. (2015).

[56] C.S. Freitas, A.C. Roveda Jr., D.R. Truzzi, A.C. Garcia, T.M. Cunha, F.Q. Cunha, D.W. Franco, J. Med Chem. (2015) (in press).

[57] M.R. Filipovic, J.L. Miljkovic, T. Nauser, M. Royzen, K. Klos, T. Shubina, W.H. Koppenol, S.J. Lippard, I. Ivanovic-Burmazovic, J. Am. Chem. Soc. 134 (2012) $12016-12027$

[58] K.N. Houk, B.N. Hietbrink, M.D. Bartberger, P.R. McCarren, B.Y. Choi, R.D. Voyksner, J.S. Stamler, E.J. Toone, J. Am. Chem. Soc. 125 (2003) 6972-6976.

[59] A. Martinez-Ruiz, S. Lamas, Cardiovasc. Res. 62 (2004) 43-52.

[60] L.L. Perissinotti, A.G. Turjanski, D.A. Estrin, F. Doctorovich, J. Am. Chem. Soc 127 (2005) 486-487.

[61] P.S.Y. Wong, J. Hyun, J.M. Fukuto, F.N. Shirota, E.G. DeMaster, D.W. Shoeman, H.T. Nagasawa, Biochemistry 37 (1998) 5362-5371.

[62] C.E. Paulsen, K.S. Carroll, Chem. Rev. 113 (2013) 4633-4679.

[63] M.L. Souza, H.A.S. Silva, D.W. Franco (in preparation).

[64] A. Zeida, C.M. Guardia, P. Lichtig, L.L. Perissinotti, L.A. Defelipe, A. Turjanski R. Radi, M. Trujillo, D.A. Estrin, Biophys. Rev. 6 (2014) 27-46.

[65] N.O. Codesido, T. Weyhermuller, J.A. Olabe, L.D. Slep, Inorg. Chem. 53 (2014) 981-997.

[66] A.C. Montenegro, S.E. Bari, J.A. Olabe, J. Inorg. Biochem. 118 (2013) 108-114.

[67] J.Y. Lee, G.B. Richter-Addo, J. Inorg. Biochem. 98 (2004) 1247-1250.

[68] D. Sellmann, T. Gottschalk-Gaudig, D. Haussinger, F.W. Heinemann, B.A. Hess, Chem. Eur. J. 7 (2001) 2099-2103.

[69] J.C.M. Pereira, M.L. Souza, D.W. Franco, Eur. J. Inorg. Chem. (2015) 1005-1011

[70] R.G. Kallen, J. Am. Chem. Soc. 93 (1971), 6227.

[71] H.M.S. Patel, D.L.H. Williams, J. Chem. Soc., Perkin Trans. 2 (1990) 37-42.

[72] D.M.E. Reuben, T.C. Bruice, J. Am. Chem. Soc. 98 (1976) 114-121.

[73] B.R. McGarvey, A.A. Ferro, E. Tfouni, C.W.B. Bezerra, I. Bagatin, D.W. Franco, Inorg. Chem. 39 (2000) 3577-3581.

[74] M. Wanner, T. Scheiring, W. Kaim, L.D. Slep, L.M. Baraldo, J.A. Olabe, S. Zalis, E.J. Baerends, Inorg. Chem. 40 (2001) 5704-5707.

[75] J.D.W. Voorst, P. Hemmeric, J. Chem. Phys. 45 (1966) 3914-3918.

[76] P.G. Zanichelli, A.M. Miotto, H.F.G. Estrela, F.R. Soares, D.M. Grassi-Kassisse, R.C. Spadari-Bratfisch, E.E. Castellano, F. Roncaroli, A.R. Parise, J.A. Olabe, A.R.M.S. de Brito, D.W. Franco, J. Inorg. Biochem. 98 (2004) 1921-1932.

[77] L.L. Perissinotti, D.A. Estrin, G. Leitus, F. Doctorovich, J. Am. Chem. Soc. 128 (2006) 2512-2513.

[78] P.N. Coneski, M.H. Schoenfisch, Chem. Soc. Rev. 41 (2012) 3753-3758.

[79] E.M. Hetrick, M.H. Schoenfisch, Annu. Rev. Anal. Chem. 2 (2009) 409-433.

[80] J.L. Heinecke, C. Khin, J.C.M. Pereira, S.A. Suarez, A.V. Iretskii, F. Doctorovich, P.C. Ford, J. Am. Chem. Soc. 135 (2013) 4007-4017. 
[81] S.A. Suarez, D.E. Bikiel, D.E. Wetzler, M.A. Marti, F. Doctorovich, Anal. Chem. 85 (2013) 10262-10269.

[82] S.A. Suarez, M.H. Fonticelli, A.A. Rubert, E. de la Llave, D. Scherlis, R.C. Salvarezza, M.A. Marti, F. Doctorovich, Inorg. Chem. 49 (2010) 6955-6966.

[83] F. Doctorovich, D.E. Bikiel, J. Pellegrino, S.A. Suarez, M.A. Marti, Acc. Chem. Res. 47 (2014) 2907-2916.

[84] B.E. Lopez, C.E. Rodriguez, M. Pribadi, N.M. Cook, M. Shinyashiki, J.M. Fukuto, Arch. Biochem. Biophys. 442 (2005) 140-148.

[85] B.E. Lopez, D.A. Wink, J.M. Fukuto, Arch. Biochem. Biophys. 465 (2007) 430-436.

[86] S. Mitroka, M.E. Shoman, J.F. DuMond, L. Bellavia, O.M. Aly, M. Abdel-Aziz, D.B. Kim-Shapiro, S.B. King, J. Med. Chem. 56 (2013) 6583-6592.

[87] C.H. Switzer, W. Flores-Santana, D. Mancardi, S. Donzelli, D. Basudhar, L.A. Ridnour, K.M. Miranda, J.M. Fukuto, N. Paolocci, D.A. Wink, Biochim. Biophys. Acta: Bioenerg. 1787 (2009) 835-840.

[88] F. Roncaroli, M.E. Ruggiero, D.W. Franco, G.L. Estiu, J.A. Olabe, Inorg. Chem. 41 (2002) 5760-5769.

[89] P.C. Ford, Coord. Chem. Rev. 5 (1970), 75

[90] F. Bottomley, Acc. Chem. Res. 11 (1978) 158-163.

[91] T.W. Swaddle, Coord. Chem. Rev. 14 (1974) 217-268.

[92] L.M. Baraldo, M.S. Bessega, G.E. Rigotti, J.A. Olabe, Inorg. Chem. 33 (1994) 5890-5896.

[93] J.C.M. Pereira, PhD Thesis, 2009.

[94] A.B.P. Lever, Inorg. Chem. 29 (1990) 1271-1285.

[95] L.K. Keefer, ACS Chem. Biol. 6 (2011) 1147-1155.

[96] J. Kim, G. Saravanakumar, H.W. Choi, D. Park, W.J. Kim, J. Mater. Chem. B 2 (2014) 341-356.

[97] M.C. Frost, M.M. Reynolds, M.E. Meyerhoff, Biomaterials 26 (2005) $1685-1693$.

[98] M.C. Jen, M.C. Serrano, R. van Lith, G.A. Ameer, Adv. Funct. Mater. 22 (2012) 239-260.

[99] D.A. Riccio, M.H. Schoenfisch, Chem. Soc. Rev, 41 (2012) 3731-3741.

[100] Y. Lu, B. Sun, C. Li, M.H. Schoenfisch, Chem. Mater. 23 (2011) 4227-4233.

[101] A.C. Roveda Jr., D.W. Franco, Braz. J. Pharm. Sci. 49 (2013) 1-14.

[102] A.B. Seabra, N. Duran, J. Mater. Chem. 20 (2010) 1624-1637.

[103] S. Sortino, Chem. Soc. Rev. 39 (2010) 2903-2913.

[104] S. Sortino, J. Mater. Chem. 22 (2012) 301-318.

[105] N.A. Stasko, T.H. Fischer, M.H. Schoenfisch, Biomacromolecules 9 (2008) 834-841.

[106] N.A. Stasko, M.H. Schoenfisch, J. Am. Chem. Soc. 128 (2006) 8265-8271.

[107] P.T. Burks, J.V. Garcia, R. Gonzalezirias, J.T. Tillman, M. Niu, A.A. Mikhailovsky, J. Zhang, F. Zhang, P.C. Ford, J. Am. Chem. Soc. 135 (2013) 18145-18152.
[108] A.A. Eroy-Reveles, Y. Leung, C.M. Beavers, M.M. Olmstead, P.K. Mascharak, J. Am. Chem. Soc. 130 (2008), 6650-6650.

[109] A.A. Eroy-Reveles, Y. Leung, P.K. Mascharak, J. Am. Chem. Soc. 128 (2006) $7166-7167$.

[110] A. Fraix, N. Kandoth, S. Sortino, in: A. Albini, E. Fasani (Eds.), Photochemistry, vol. 41, The Royal Society of Chemistry, Cambridge, 2013.

[111] J.V. Garcia, J.P. Yang, D.K. Shen, C. Yao, X.M. Li, R. Wang, G.D. Stucky, D.Y. Zhao, P.C. Ford, F. Zhang, Small 8 (2012) 3800-3805.

[112] G.M. Halpenny, M.M. Olmstead, P.K. Mascharak, Inorg. Chem. 46 (2007) 6601-6606.

[113] G.M. Halpenny, R.C. Steinhardt, K.A. Okialda, P.K. Mascharak, J. Mater. Sci. Mater. Med. 20 (2009) 2353-2360.

[114] A.C. Roveda Jr., H.D. Aguiar, K.M. Miranda, C.C. Tadini, D.W. Franco, J. Mater. Chem. B 2 (2014) 7232-7242.

[115] A.C. Roveda Jr., T.B.R. Papa, E.E. Castellano, D.W. Franco, Inorg. Chim. Acta 409 (Pt A) (2014) 147-155.

[116] T.A. Johnson, N.A. Stasko, J.L. Matthews, W.E. Cascio, E.L. Holmuhamedov, C.B Johnson, M.H. Schoenfisch, Nitric Oxide 22 (2010) 30-36.

[117] A.P. Dicks, H.R. Swift, D.L.H. Williams, A.R. Butler, H.H. AlSadoni, B.G. Cox, J. Chem. Soc., Perkin Trans. 2 (1996) 481-487.

[118] A.J. Holmes, D.L.H. Williams, J. Chem. Soc., Perkin Trans. 2 (2000) 1639-1644.

[119] H. Al-Sa'doni, A. Ferro, Clin. Sci. (Lond.) 98 (2000) 507-520.

[120] H.D. Aguiar, A.C. Roveda Jr., R.D. Piva, K.A. Onoda, A.A. Miyakawa, J.E. Krieger, D.W. Franco, C.C. Tadini, J. Appl. Polym. Sci. 132 (2015).

[121] J.C. Toledo, L.G.D. Lopes, A.A. Alves, L.P. da Silva, D.W. Franco, J. Inorg. Biochem. 89 (2002) 267-271.

[122] E.M. Hetrick, M.H. Schoenfisch, Chem. Soc. Rev. 35 (2006) 780-789.

[123] F.O.N. Silva, E.C.C. Gomes, T.D. Francisco, A.K.M. Holanda, I.C.N. Diogenes, E.H.S. de Sousa, L.G.F. Lopes, E. Longhinotti, Polyhedron 29 (2010) 3349-3354.

[124] S. Hwang, W. Cha, M.E. Meyerhoff, Angew. Chem. Int. Ed. 45 (2006) $2745-2748$

[125] S. Hwang, M.E. Meyerhoff, Biomaterials 29 (2008) 2443-2452.

[126] K. Liu, M.E. Meyerhoff, J. Mater. Chem. 22 (2012) 18784-18787.

[127] T.C. Major, D.O. Brant, C.P. Burney, K.A. Amoako, G.M. Annich, M.E. Meyerhoff, H. Handa, R.H. Bartlett, Biomaterials 32 (2011) 5957-5969.

[128] B.K. Oh, M.E. Meyerhoff, J. Am. Chem. Soc. 125 (2003) 9552-9553.

[129] B.K. Oh, M.E. Meyerhoff, Biomaterials 25 (2004) 283-293.

[130] J.Y. Jeremy, P. Gadsdon, N. Shukla, V. Vijayan, M. Wyatt, A.C. Newby, G.D. Angelini, Biomaterials 28 (2007) 895-908.

[131] E.D. Glendening, C.R. Landis, F.J. Weinhold, J. Comput.Chem. 34 (2013) 1429-1437. 